Award Number: W81XWH-05-1-0121

TITLE: To investigate the Therapeutic Efforts of the COX-2 Inhibitor NS-398 as a Single Agent, and in Combination with Vitamin D, in Vitro and in Vivo

PRINCIPAL INVESTIGATOR: Yi-Fen Lee, Ph.D.

CONTRACTING ORGANIZATION: University of Rochester

Rochester, NY 14627-0140

REPORT DATE: January 2006

TYPE OF REPORT: Annual

PREPARED FOR: U.S. Army Medical Research and Materiel Command

Fort Detrick, Maryland 21702-5012

DISTRIBUTION STATEMENT: Approved for Public Release;

Distribution Unlimited

The views, opinions and/or findings contained in this report are those of the author(s) and should not be construed as an official Department of the Army position, policy or decision unless so designated by other documentation. 


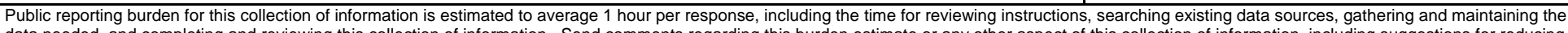

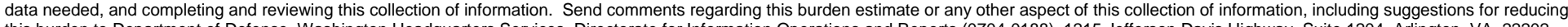

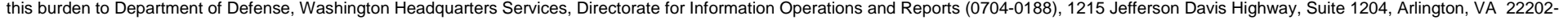

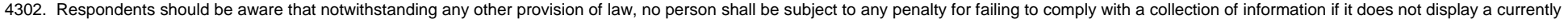
valid OMB control number. PLEASE DO NOT RETURN YOUR FORM TO THE ABOVE ADDRESS.

\begin{tabular}{l|l} 
1. REPORT DATE $(D D-M M-Y Y Y Y)$ & 2. REPORT TYPE
\end{tabular}

01-01-2006

4. TITLE AND SUBTITLE

Single Agent, and in Combination with Vitamin D, in Vitro and in Vivo
To investigate the Therapeutic Efforts of the COX-2 Inhibitor NS-398 as a

\section{DATES COVERED (From - To)} 30 DEC 2004 - 29 DEC 2005 5a. CONTRACT NUMBER

5b. GRANT NUMBER

W81XWH-05-1-0121

5c. PROGRAM ELEMENT NUMBER

5d. PROJECT NUMBER

6. AUTHOR(S)

Yi-Fen Lee, Ph.D.

5e. TASK NUMBER

5f. WORK UNIT NUMBER

E-mail: yifen_lee@urmc.rochester.edu

7. PERFORMING ORGANIZATION NAME(S) AND ADDRESS(ES)

University of Rochester

Rochester, NY 14627-0140

9. SPONSORING I MONITORING AGENCY NAME(S) AND ADDRESS(ES)

U.S. Army Medical Research and Materiel Command

Fort Detrick, Maryland 21702-5012

\section{DISTRIBUTION I AVAILABILITY STATEMENT}

Approved for Public Release; Distribution Unlimited

\section{SUPPLEMENTARY NOTES}

\section{ABSTRACT}

The incidence of prostate cancer has increased rapidly and much effort is needed towards understanding the mechanisms involved in development and progression of prostate cancer and developing new strategies for its prevention and treatment. Recent studies have suggested that nonsteroidal anti-inflammatory drugs (NSAIDs), such as COX-2 inhibitor act as chemopreventative agents. Prostate Tissue Microarray analyses found that COX-2 expression in prostate cancer was correlated with cancer progression. Treatment of prostate cancer cells with a selective COX-2 inhibitor, NS-398, induces VDR expression, and thus might result in increasing the vitamin D sensitivity. In return, treatment of prostate cancer cells with 1,25VD results in reduction of COX-2 expression. Based on the bi-directional regulation involving vitamin D and the COX-2 inhibitor, we hypothesize that combining vitamin D and a COX-2 inhibitor in the treatment of prostate cancer will be beneficial to the treatment of prostate cancer. Four aims are proposed. 1: Evaluation of the molecular mechanism of COX-2 inhibitor NS398 action on the growth of prostate cancer cells. 2: Evaluation of the effects of 1,25-VD and its analogs in combination with COX-2 inhibitor on progression of prostate cancer cells. 3: Evaluation of the underlying mechanism of the bi-directional regulatory pathways between the COX-2 inhibitor NS-398 and vitamin D. 4:Evaluation of the effects of COX-2 inhibitor, administered in combination with vitamin $\mathrm{D}$ compounds, on prostate cancer progression and invasion in vivo

\section{SUBJECT TERMS}

No subject terms provided.

\section{SECURITY CLASSIFICATION OF:}

a. REPORT

b. ABSTRACT

U
17. LIMITATION OF ABSTRACT c. THIS PAGE
U
UU

\begin{tabular}{|c|l|}
$\begin{array}{c}\text { 18. NUMBER } \\
\text { OF PAGES }\end{array}$ & $\begin{array}{l}\text { 19a. NAME OF RESPONSIBLE PERSON } \\
\text { USAMRMC }\end{array}$ \\
\cline { 2 - 2 } 26 & $\begin{array}{l}\text { 19b. TELEPHONE NUMBER (include area } \\
\text { code) }\end{array}$ \\
\hline
\end{tabular}




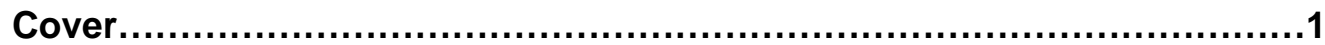

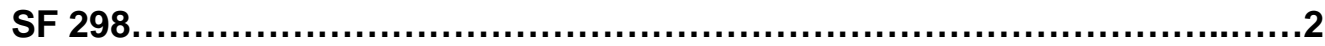

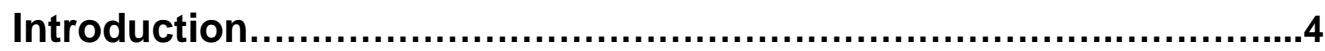

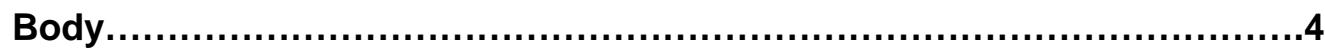

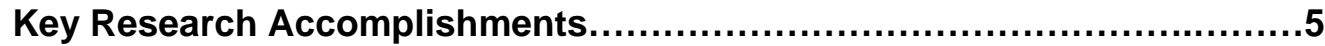

Reportable Outcomes.........................................................6

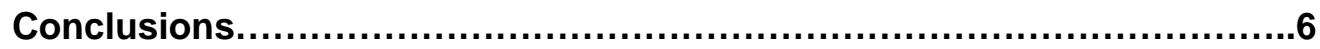

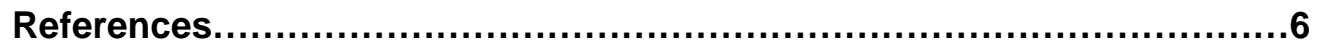

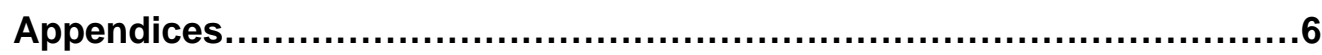




\title{
TO INVESTIGATE THE THERAPEUTIC EFFECTS OF THE COX-2 INHIBITOR NS-398 AS A SINGLE AGENT, AND IN COMBINATION WITH VITAMIN D, IN VITRO AND IN VIVO
}

\author{
Introduction and Body:
}

\section{A summary of this proposal was the follow statement}

The incidence of prostate cancer has increased rapidly during the past decades and it has now become the most common malignancy of men in many Western nations. In the USA, prostate cancer represents the second leading cause of cancer death in men. ost prostate cancer initially responds to androgen ablation treatment, however, eventually it relapses to an androgen-independent state, leading to tumor outgrowth. Therefore, much effort is needed towards understanding the mechanisms involved in development and progression of prostate cancer and developing new strategies for its prevention and treatment.

Results of recent epidemiologic and animal model studies have suggested that nonsteroidal anti-inflammatory drugs (NSAIDs), which prevent biosynthesis of prostagladins, biosynthesis through inhibition of COX activity, act as chemopreventative agents. We examined the expression of COX-2 in prostate cancer tissue arrays, which consist of normal, BPH, PIN, and low-and high-grade prostate tumor samples. In our preliminary study we found that COX-2 expression is significantly higher in cancer than in normal or BPH prostate samples and the tendency of COX-2 expression in prostate cancer cells is consistent with prostate cancer cell lines, implying COX-2 expression in prostate cancer might be up-regulated during cancer progression. Treatment of prostate cancer cells with a selective COX-2 inhibitor, NS-398, induces VDR expression, and thus might result in increasing the vitamin D sensitivity of such cells. In return, treatment of prostate cancer cells with 1,25-VD results in reduction of COX-2 mRNA expression, but not COX-1 expression.

Based on the bi-directional regulation involving vitamin $\mathrm{D}$ and the COX-2 inhibitor, we hypothesize that combining vitamin $\mathrm{D}$ and a COX-2 inhibitor in the treatment of prostate cancer will be beneficial to the treatment of prostate cancer.

In this proposal, we will examine the effects of combination of 1,25-VD, its analog (EB1089), and a COX-2 inhibitor NS-398, compared with single agent treatment, on prostate cancer growth, apoptosis, invasion, angiogenesis, and neuroendocrine differentiation in vitro and in vivo. Four Specific Aims are proposed.

AIM 1: Evaluation of the molecular mechanism of COX-2 inhibitor NS-398 action on the growth of prostate cancer cells.

AIM 2: Evaluation of the effects of $1,25-\mathrm{VD}$ and its analogs in combination with COX-2 inhibitor on progression of prostate cancer cells.

AIM 3: Evaluation of the underlying mechanism of the bi-directional regulatory pathways between the COX-2 inhibitor NS-398 and vitamin D.

AIM 4: Evaluation of the effects of COX-2 inhibitor, administered in combination with vitamin D compounds, on prostate cancer progression and invasion in vivo.

Our proposed schedule for completion of this proposal included the following tasks during the first 12 month.

Task1: Determine whether the inhibition of growth mediated by NS-398 is a COX-2-dependent pathway. (Month 1-6)

Measure the COX-2 protein level and prostaglandin secretion level

Restore NS-398 effect by adding prostaglandin

Task 2: Determine the NS-398 mediated anti-tumor pathways. (Month 1-12)

Anti-proliferation

Anti-invasion

Anti- tumorigenesis

Anti-angiogenesis

Task 3: Determine the molecules that are responsible for NS-398 anti-tumor action. (Month 
6-18)

RT-PCR, and real-time PCR analysis of expression of known genes involved in NS-398 action

DNA array analysis

Key Research Accomplishments and Reportable Outcomes:

Our progresses and competition of Task 1, 2 and 3 have generated two publications (please see the appendix). These two publications cover the roles of 1,25-vitamin D3/VDR cross-talk with androgen/androgen receptor, the key factor control the prostate cancer growth, as well as how 1,25-Vitamin D3 inhibit prostate cancer invasion via modulate several proteinase activities. Both of publication can serve as the base for investigation of combination effects of 1,25-vitamin D3 and COX-2 inhibitors for inhibition prostate cancer progression. We have also tested the COX-2 inhibitor NS-398 effects on VDR/1,25-Vitamin D3 down-stream targeted genes CYP24 expression by Real-time quantification PCR. As shown in Figure 1, in both PC3, and LNCaP cells, applying NS-398 into the cells reduced the VDR mRNA expression as well as VDR/1,25-Vitamin D3 targeted genes CYP24 expression significantly.

In addition to these two publications, COX-2 RNAi has generated to confirm the specificity of COX-2 action in prostate. We will use COX-2 RNAi for further analyses.

Most importantly, we have started animal studies to examine the combination effects of COX-2 inhibitor NS-398 and 1,25-Vitamin D3. Human prostate cancer xenograft in an athymic mouse model, which mimics prostate cancer progression in vivo has established. Young adult male mice, at age of 6-8 weeks will be subcutaneously injected with $2.5 \times 10^{6}$ LNCaP cells. Tumors will be allowed to grow, measured weekly with calipers, and tumor volumes will be calculated using the formula $0.532 \mathrm{x}$ $r 1^{2} \times r 2(r 1<r 2)$. Once tumors reach a volume of $0.5-1.0 \mathrm{~cm}^{3}$, animals will be randomly grouped in two categories: (1) castration alone, or (2) castration plus EB1089, NS-398, or a combination of both. As shown in Figure 2, a significant suppression effect on the all treatment group from our pilot in vivo experiments in which 2 animals in each experiments. We will continue to examine with more animals for each group in the coming year.
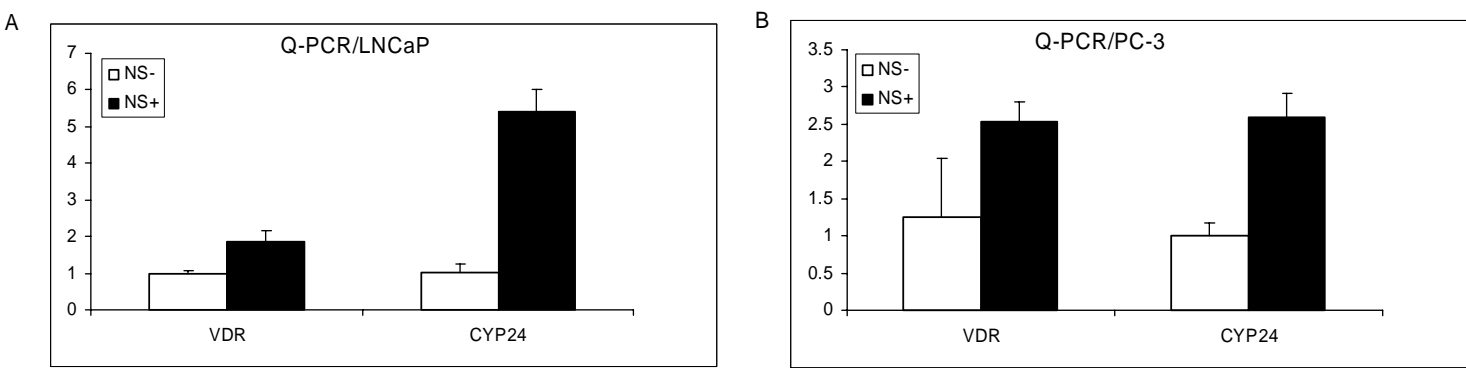

Figure 1. Induction of VDR, and CYP24 mRNA expressions by applying COX-2 inhibitor NS-398 to LNCaP and PC-3 prostate cancer cells. LNCaP, and PC-3 cells were seeded, and then treatment with NS-398 $(25 \mu \mathrm{M})$ for $12 \mathrm{hrs}$, and then cells were harvested and total RNA were extracted. cDNA from the two cell lines were synthesized by reverse transcription. Real-Time PCR will be performed using the Bio-Rad iQ cycler. CT values were calculated and normalized to the level of the housekeeping gene $\beta$-microglobulin. Relative gene expression were calculated according to $2^{-\Delta \mathrm{CT}}$ from three independent experiments. 


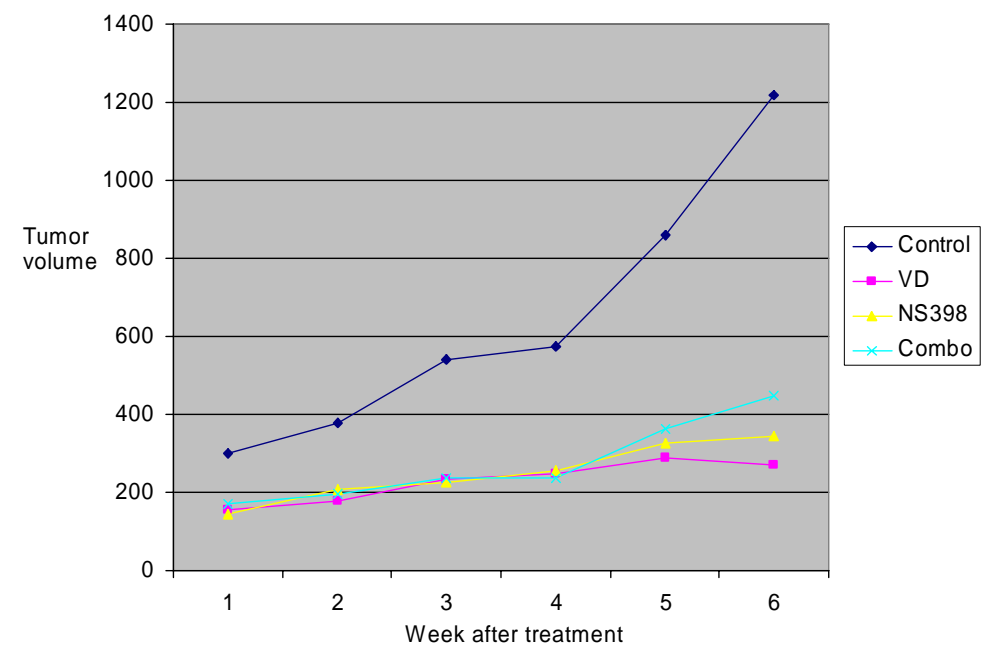

Figure 2. The anti-tumor effects of 1,25-Vitamin D3, NS-398, and combination effects in the LNCaP-xenograft nude mouse. Young adult male mice, at age of 8 weeks were subcutaneously injected with $2.5 \times 10^{6} \mathrm{LNCaP}$ cells, and allow tumor to grow. Tumor volumes were calculated using the formula $0.532 \times r 1^{2} \times r 2(r 1<r 2)$, and once the tumor reached to $0.5 \mathrm{~cm}^{3}$, mice were treated with 1) control, 2) 1,25-vitamin D3 (3 $\mu \mathrm{g} / \mathrm{kg})$, NS-398 (1.5 mg/Kg), and combination twice per week, and tumor size were measured. The data were generated from two mice each group.

\section{Conclusion:}

As we demonstrated in our progression report, this project has moved smoothly and during this period, we generated two papers in regards to the vitamin D anti-prostate cancer action. In continue of this study we have started in vivo studies as well as established all the essential tools for further dissection the molecular mechanisms for this combination effects. We expected we will be able to obtain more promising data and then allow us to apply this concept into the clinical application.

\section{References and Appendices:}

1. Ting H.-J., Bao B.-Y, and Lee, Y.-F., Androgen Receptor Coregulators Mediate the Suppressive Effect of Androgen Signals on Vitamin D receptor Activity. Endocrine 26(1): 1-10, 2005.

2. Bao B.-Y., Yeh, S.-D., and Lee, Y.-F., $1 \alpha$, 25-dihydroxyvitamin $\mathrm{D}_{3}$ inhibits prostate cancer cell invasion via modulation of selective protease. Carcinogenesis, 27(1): 32-42, 2006. 


\title{
Androgen-Receptor Coregulators Mediate the Suppressive Effect of Androgen Signals on Vitamin D Receptor Activity
}

\author{
Huei-Ju Ting, ${ }^{1, *}$ Bo-Ying Bao, ${ }^{2, *}$ Cheng-Lung Hsu, ${ }^{1}$ and Yi-Fen Lee ${ }^{1}$ \\ Departments of ${ }^{1}$ Urology and ${ }^{2}$ Chemical Engineering, University of Rochester, 601 Elmwood Ave., Rochester, NY 14642
}

Overexpression of androgen receptors (AR) in PC-3 cell, and treatment of $5 \alpha$-dihydrotestosterone in LNCaP cells lead to the suppression of VDR transactivation. Competition for shared coregulators between AR and VDR is one possible mechanism to explain the suppressive effect of androgen-AR signals on VDR activity. Among the AR coregulators we tested, ARA54, ARA70, supervillin, and gelsolin were found to enhance VDR transactivation. Further characterization of the interaction between ARA54 or ARA70 and VDR demonstrated a direct interaction between VDR and ARA70, but no association between ARA54 and VDR. The LXXLL motif of ARA70 is essential for interaction with VDR and partially responsible for its function as a coactivator of VDR. The suppression of VDR transactivation by AR signal was restored by overexpression of ARA70, but not ARA54. Together, ARA70 and ARA54 modulate VDR transactivation, and the competition for ARA70 mediates the suppressive effect of androgen-AR on VDR transactivation.

Key Words: $1 \alpha, 25$-Dihydroxyvitamin $\mathrm{D}_{3}$; vitamin $\mathrm{D}_{3}$ receptor; androgen receptor; coregulators.

\section{Introduction}

Treatment with $1 \alpha, 25$-dihydroxyvitamin $\mathrm{D}_{3}(1,25$-VD) inhibits proliferation and promotes differentiation in several types of cancers (1). The implications for clinical usefulness has triggered a number of studies regarding the use of 1,25-VD to treat prostate cancer (PCa) (2). Among several established human $\mathrm{PCa}$ cell lines, including $\mathrm{LNCaP}$, DU145, PC-3, ALVA-3, and MDA PCa, treatment with 1,25VD led to antiproliferation effects, but in varying degrees $(3,4)$. For example, DU145, PC-3, ALVA-3, and MDA PCa

*These two authors contributed equally to this paper.

Received November 8, 2004; Revised December 15, 2004; Accepted December 16, 2004.

Author to whom all correspondence and reprint requests should be addressed: Yi-Fen Lee, PhD, Departments of Urology and Chemical Engineering, University of Rochester, 601 Elmwood Ave., Rochester, NY 14642. E-mail: YiFen_Lee@urmc.rochester.edu 2a display less growth inhibition with $1,25-\mathrm{VD}(<20 \%$ inhibition) than LNCaP and MDA PCa 2b (approx 50\%). These varied degrees of 1,25 -VD growth inhibition indicate cells develop resistance to 1,25-VD treatment and hence become less sensitive to 1,25 -VD. The receptor for 1,25 VD (VDR), which transmits the ligand signal to the nucleus and regulates the transcription of target genes, is universally expressed in the PCa cells studied $(3,4)$. The antiproliferation effect of 1,25-VD is suggested to be partly correlated with VDR expression level and transactivity (3). Signals affecting VDR activity are potentially involved in the development of 1,25-VD resistance. The fact that 1,25-VD-resistant cells are also androgen-independent implies that the defects in 1,25-VD signaling may be a result of the altered molecular context derived in such forms of PCa.

Androgens are important for the growth of $\mathrm{PCa}$, and antiandrogens have been used therapeutically for decades. Pharmacological or surgical androgen ablation therapy is commonly used to treat PCa patients. Although tumors shrink significantly after therapy, the majority of patients develop hormone-refractory PCa. Numerous mechanisms revealed to date demonstrate that diverse signaling pathways are involved in developing resistance to androgen ablation (5). First, mutant ARs with broad ligand sensitivity have been found to utilize hormones other than androgen to transmit growth-promoting signals (5). Second, amplification of growth hormone signals, such as HER2/neu, in PCa can stimulate growth and eventually bypass $\mathrm{AR}(5)$. Third, overexpression of coregulators, such as SRC-1, TIF-2, and gelsolin, in androgen-independent PCa has been shown, that may magnify AR activity in the presence of trace amounts of androgen $(6,7)$. A more recent finding also demonstrated that hydroxyflutamide, an antiandrogen, could activate the MAPK pathway, an effect that might contribute to the development of PCa resistance to androgen ablation (8). Either one of mechanisms or a combination of several mechanisms described above can result in the development of androgenindependent cell growth, and therefore play roles in 1,25VD resistance.

Most coregulators associate with and modulate more than one steroid receptor. AR coregulators, originally identified as AR-associated proteins, also modulate many other steroid receptors. As previously reported, ARA54 enhances AR and progesterone receptor (9); ARA70 enhances peroxisome 
proliferator activated receptor $\gamma$ and AR (10); and gelsolin and supervillin enhance $\mathrm{AR}$ and glucocorticoid receptor $(7,11)$. It is highly possible that VDR and AR share the same coregulators and the potential cross-talk between VDR and androgen-AR signals mediated by coregulators might account for vitamin D action in PCa. Therefore, evaluation of the function of androgen-AR signals and AR coregulators on VDR activity is the first step to elucidate their roles in vitamin $D$ response. Here we characterize the effects of androgen-AR signals and AR coregulators on VDR transactivity, which may provide us information about potential mechanisms of 1,25-VD resistance in PCa cells.

\section{Results}

\section{Androgen Signaling Suppresses VDR Transactivation}

We tested how androgen-AR signals influence 1,25-VD signaling through VDR. The 1,25-VD-induced VDR activity is measured by the activation of VDR target gene, rat CYP24 promoter-controlled reporter gene, rCYP24-LUC. Overexpression of AR in PC-3 suppresses the 1,25-VDinduced VDR transactivation (Fig. 1A, lane 2 vs 5), with further suppression after addition of the androgen, $5 \alpha$-dihydrotestosterone (DHT) (lane 5 vs 6). On the other hand, DHT treatment in the AR-containing cells, LNCaP, suppresses VDR activity (Fig. 1B). To examine whether the VDR amount was reduced after DHT treatment, we compared the VDR protein levels. As shown in Fig. 1C, the protein level of VDR was increased under the treatment of DHT (lane 3 vs lane 2). Therefore, the suppression of VDR activity by androgenAR signals is not due to reduced amount of VDR under DHT treatment. The overexpression of AR in PC-3 and activation of AR in LNCaP, both suppress VDR transactivation, suggesting a possible cross-talk between AR and VDR in gene regulation.

\section{Some of AR Coregulators Modulate VDR Transactivation}

To investigate the cross-talk between AR and VDR signaling, we hypothesize that coregulators shared by VDR and AR may mediate the cross-talk between 1,25-VD and androgen signaling pathways. We have screened several known AR coregulators for their ability to modulate VDR transactivation. The COS-1 cell line was selected for examination of coregulators' effect on VDR due to the absence of most steroid receptors, which eliminates interference from other steroid receptors. Among several AR coregulators examined, ARA54, ARA70, gelsolin, and supervillin were found to enhance VDR (Fig. 2), whereas ARA55 and ARA24 had no effect on 1,25-VD-induced VDR transactivation (data not shown). SRC-1 and SMRT, the known VDR coactivator and corepressor, respectively, served as controls.

The relative expression levels of coregulators and VDR may affect coregulator function. By defining the minimum and maximum activity of coregulators, we can determine
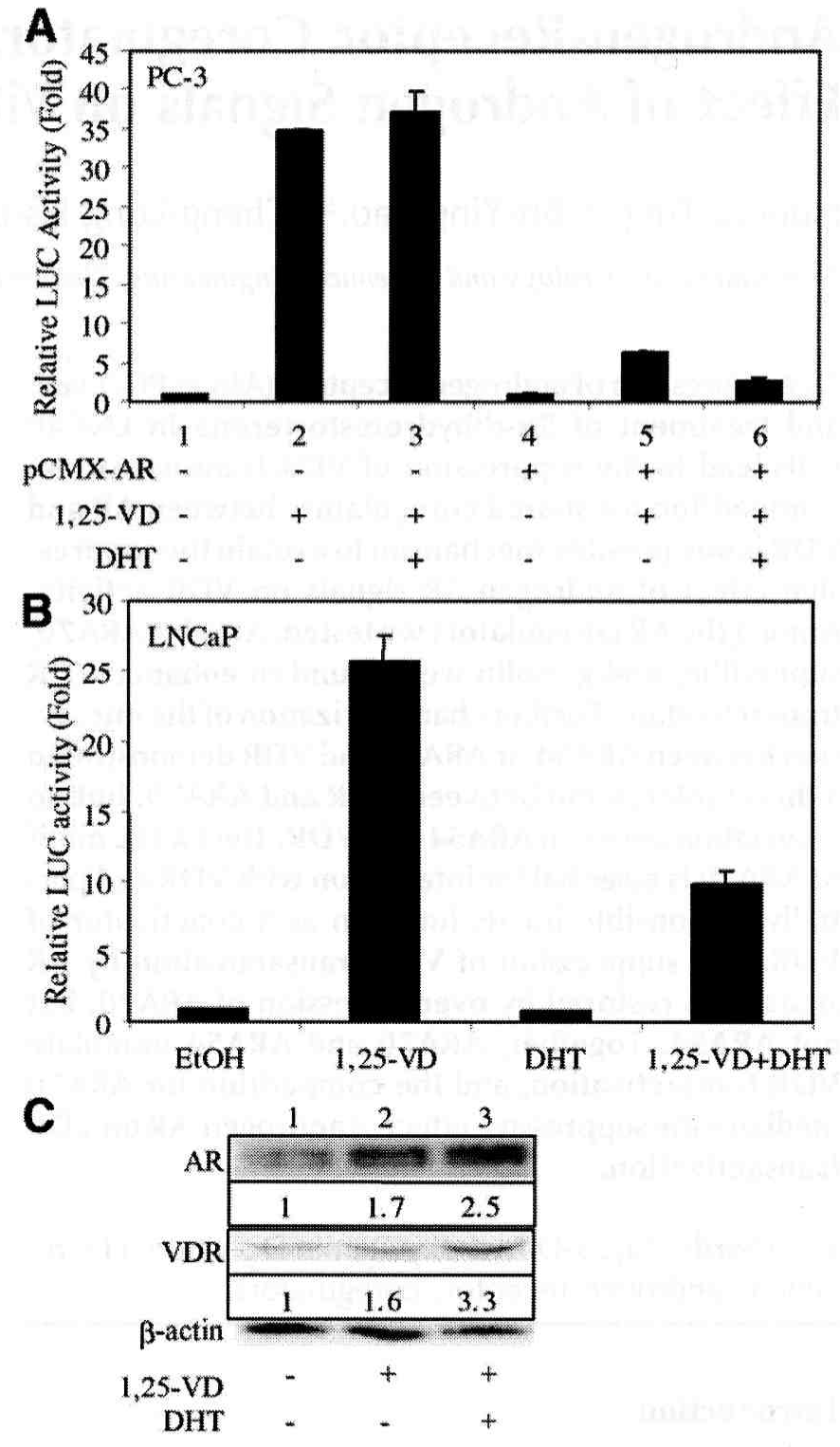

Fig. 1. Modulation of VDR transactivity by androgen-AR signal. (A) PC-3 cells were plated at a density of $10^{5}$ cells/well in 24 -well plate. Cells were co-transfected with $0.375 \mu \mathrm{g} \mathrm{pCMV}$ or pCMVAR, $0.125 \mu \mathrm{g}$ prCYP24-LUC, and $1 \mathrm{ng}$ pRL-SV40 by SuperFect. After $20 \mathrm{~h}$, cells were treated with EtOH or $10^{-7} M 1,25$-VD for another $24 \mathrm{~h}$ before being harvested. The LUC activity relative to lane 1 was calculated and the mean \pm SD of three independent experiments is shown. (B) LNCaP cells were plated at a density of $3 \times 10^{4}$ cells/well in 24 -well plates. After $24 \mathrm{~h}$, cells were transfected with $0.6 \mu \mathrm{g}$ prCYP24-LUC and $1 \mathrm{ng}$ pRL-SV40 by SuperFect. After 20 h, cells were treated with EtOH, 1,25-VD or DHT, as indicated, for another $24 \mathrm{~h}$. Cells were then harvested for the LUC assay. The LUC activity relative to lane 1 was calculated and the mean $\pm \mathrm{SD}$ of three independent experiments is shown. (C) The expression of AR and VDR after treatment in LNCaP cells was detected by Western blotting. $\mathrm{LNCaP}$ was seeded at a density of $10^{6}$ cells/dish in $100 \mathrm{~mm}$ dishes. After treating with ligands as indicated for $24 \mathrm{~h}$, cell lysates were harvested for the detection of AR, VDR, and actin expression amount. The level of expression was extrapolated by densitometric analysis after correction by actin amount. 

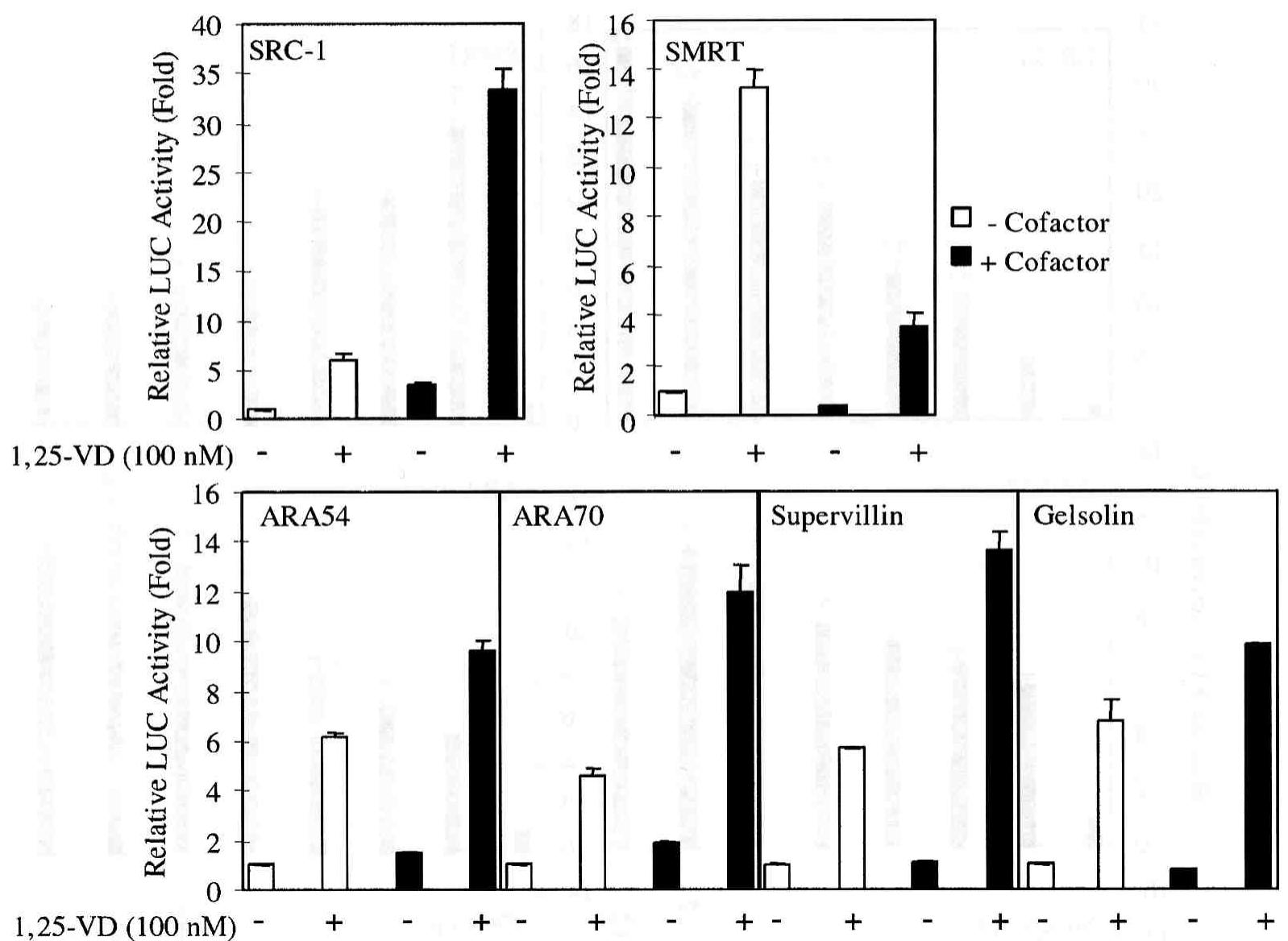

Fig. 2. The effects of coregulators on VDR transcriptional activity in COS-1 cells. COS- 1 cells were plated at a density of $3 \times 10^{4}$ cells/ well in 24-well plates, $24 \mathrm{~h}$ later cells were co-transfected with pSG5-AR or $0.2 \mu \mathrm{g} \mathrm{pSG5-VDR,} 0.6 \mu \mathrm{g}$ coregulator expression vector or empty vector, and $0.2 \mu \mathrm{g}$ prCYP24-LUC by SuperFect. After transfection overnight, cells were then incubated with either EtOH or $10^{-7} M 1,25$-VD. After $24 \mathrm{~h}$, cell lysates were prepared and used for LUC assay. The LUC activity relative to lane 1 was calculated and the mean $\pm \mathrm{SD}$ of three independent experiments is shown.

coregulator efficiency and the influence of cellular context on coregulator function. Therefore, we titrated the relative coregulator plasmid compared with that of VDR from 1 to 1 up to 8 to 1 . SRC-1 was found to enhance VDR and SMRT was found to repress VDR activity starting at a ratio of 1 to 1 , while most AR coregulators tested were found to enhance VDR starting at a ratio of 4 to 1 (Fig. 3). Among AR coregulators, ARA70 was shown to be the strongest enhancer of VDR activity, whereas gelsolin and ARA54 showed the weakest enhancement of VDR transactivity in COS-1 cells. Therefore, we focused on ARA70 and ARA54 to further dissect their mechanisms of actions.

\section{ARA70 Directly Associates with VDR But Not ARA54}

Most coregulators associate with nuclear receptors and then modulate receptor activity. We determined whether ARA54 and ARA70N associated with VDR using the mammalian two-hybrid and GST pull-down assays. Some proteins may lose their function when conjugated with Gal4 (DBD) or VP16. Therefore, we selected the one with proper function maintained after conjugation with Gal4(DBD) or
VP16 for mammalian two-hybrid assay. To ensure these conjugated coregulators have proper function, we demonstrated that Gal-ARA54C can interact with VP16-AR; VP16VDR can interact with Gal-RXR $\alpha-L B D$; and the VP16ARA70N interacts with Gal-AR, which were used as positive controls (Fig. 4A). Co-transfection of plasmids expressing Gal-ARA54C with VP16-VDR demonstrated minor interaction between VDR and ARA54C (Fig. 4A). On the other hand, Gal-VDR interacted with VP16-ARA70N in a liganddependent manner in the two-hybrid system (Fig. 4A). We further demonstrated the interaction by using in vitro GST pull-down assay, which showed ligand-independent interaction between ARA70 and VDR-L (Fig. 4B), whereas there was no interaction between ARA54 and VDR-L. The ligand-independent interaction between ARA70 and VDRL in GST-pull down assay while ligand-dependent interaction between ARA70N and VDR in mammalian two-hybrid assay implied another interaction domain may be located in the C-terminus of ARA70 that is responsible for such interaction. It may also result from fusion protein characteristics, or differences in the overall assay environments. 

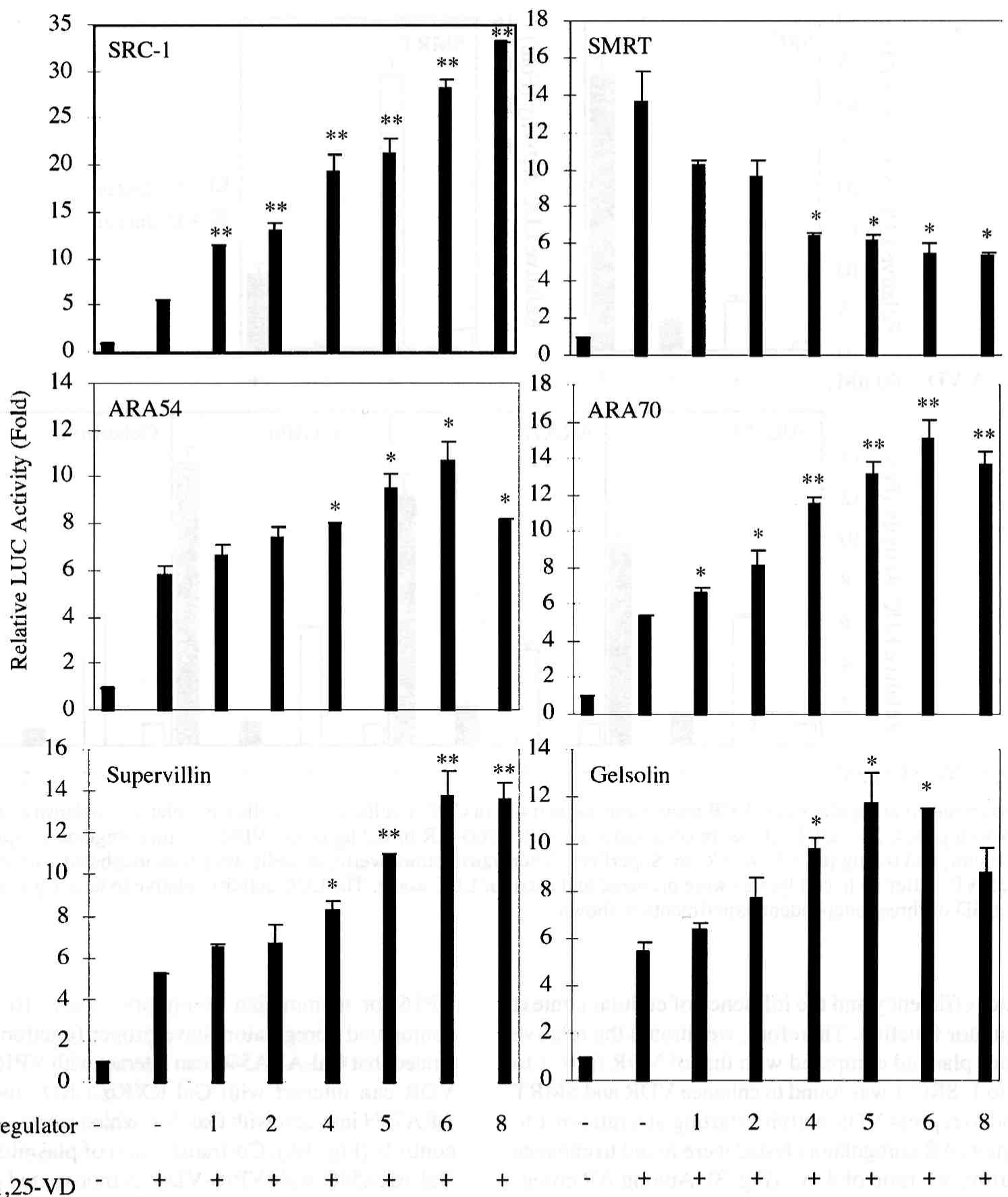

Fig. 3. The titration of coregulators shows dose-dependent effects in promoting VDR transcriptional activity. COS-1 cells were plated and transfected as described in Fig. 2 except that relative amounts of plasmids encoding coregulators to plasmids encoding VDR ranging from 1 to 1 up to 8 to 1 were transfected. The total amount of transfected plasmids was adjusted to $1 \mu \mathrm{g} / \mathrm{well}$ by addition of the empty vector. After transfection overnight cells were then incubated with EtOH or $10^{-7} M 1,25-\mathrm{VD}$. After $24 \mathrm{~h}$, cell lysates were prepared and used for LUC assay. The LUC activity relative to lane 1 was calculated and the mean \pm SD of three independent experiments is shown. $* p<0.05 ; * * p<0.01$ significant differences compared with 1,25-VD treated groups.

\section{LXXLL Motif in ARA70 \\ Is Important for Interaction with VDR}

LXXLL sequence motifs are important for most coregulators, including SRC-1, TIF-II, and NCoR, to associate with steroid receptors, such as estrogen receptor, RXR, and VDR. There is one LXXLL motif in ARA70 located in its $\mathrm{N}$-terminus. Point-mutated ARA70N containing LXXAA instead of LXXLL was constructed and characterized for its interaction ability with VDR. By using mammalian twohybrid assay, we demonstrated that VP16-ARA70N mutant (LXXAA) lost the interaction with Gal4(DBD)-VDR indicating the LXXLL motif in ARA70N is essential for interaction with VDR (Fig. 5A). We further tested the ability of mutant ARA70 to promote VDR transactivity. Overexpres- 

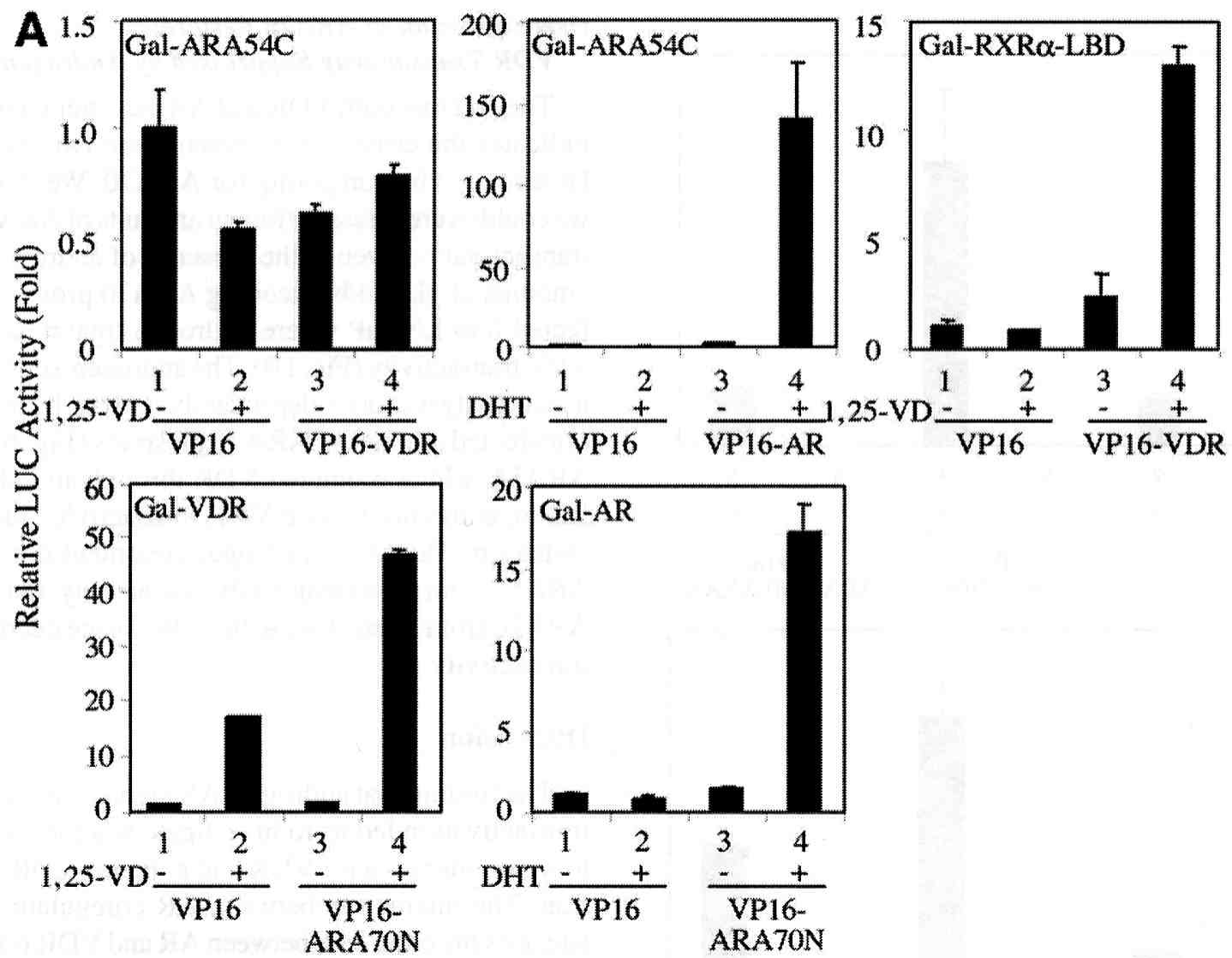

B
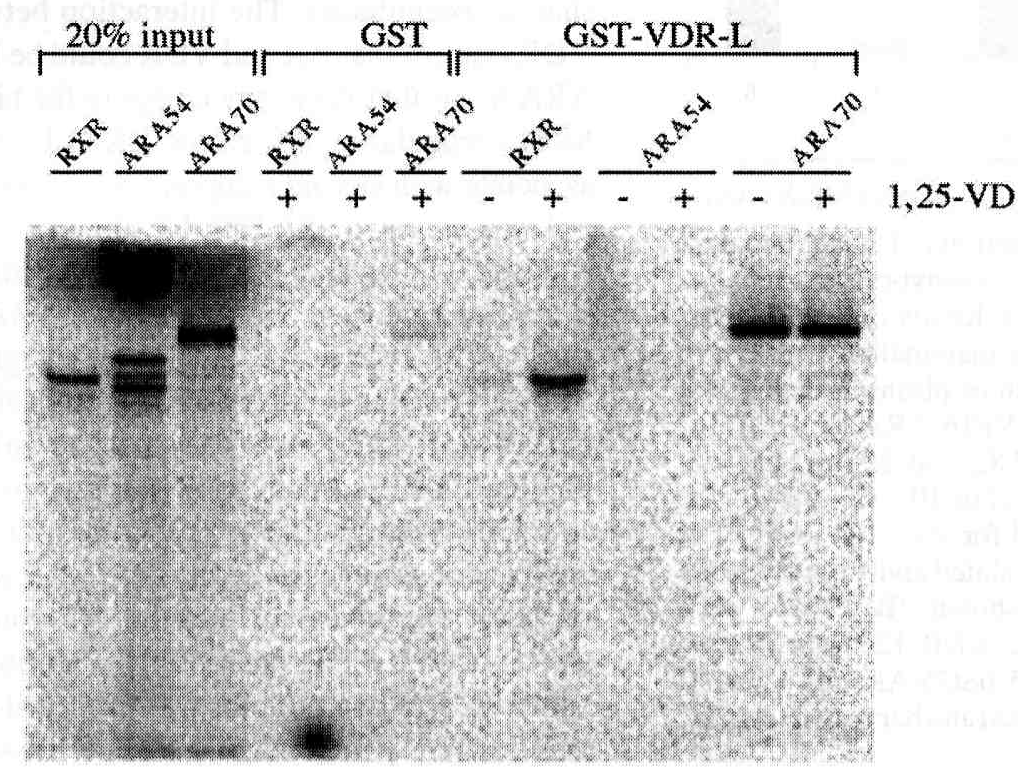

Fig. 4. The interaction between VDR and ARAs was analyzed in mammalian two-hybrid and GST pull-down assays. (A) COS-1 cells were plated at a density of $3 \times 10^{4}$ cells/well in 24 -well plates. After $24 \mathrm{~h}$, the mammalian two-hybrid assay was performed by co-transfection of plasmids expressing $0.2 \mu \mathrm{g}$ Gal-VDR, -RXR $\alpha$-LBD, or -ARAs, $0.2 \mu \mathrm{g}$ VP16, VP16-VDR, -AR or -ARAs, $0.1 \mu \mathrm{g}$ pG5-LUC, and $1 \mathrm{ng}$ pRL-SV40 as indicated. After $20 \mathrm{~h}$, cells were treated with EtOH, $10^{-8} M \mathrm{DHT}$, or $10^{-7} M 1,25$-VD for another $24 \mathrm{~h}$, and were then harvested for the LUC assay. The LUC activity relative to lane 1 was calculated and the mean \pm SD of three independent experiments is shown. (B) GST and GST-VDR-L proteins were expressed and purified from bacteria. Full-length RXR, ARA54, and ARA70 were expressed in vitro and labeled with ${ }^{35} \mathrm{~S}$ ]methionine. After incubating with EtOH or $10^{-6} M 1,25-\mathrm{VD}$ for $1 \mathrm{~h}$ at $4^{\circ} \mathrm{C}$, GST-VDR-L was further incubated with RXR, ARA54, or ARA70 for another $2 \mathrm{~h}$. The pull-down complexes were separated by $12 \%$ SDS-PAGE and analyzed by phosphorimager for the detection of radioactive signals. 

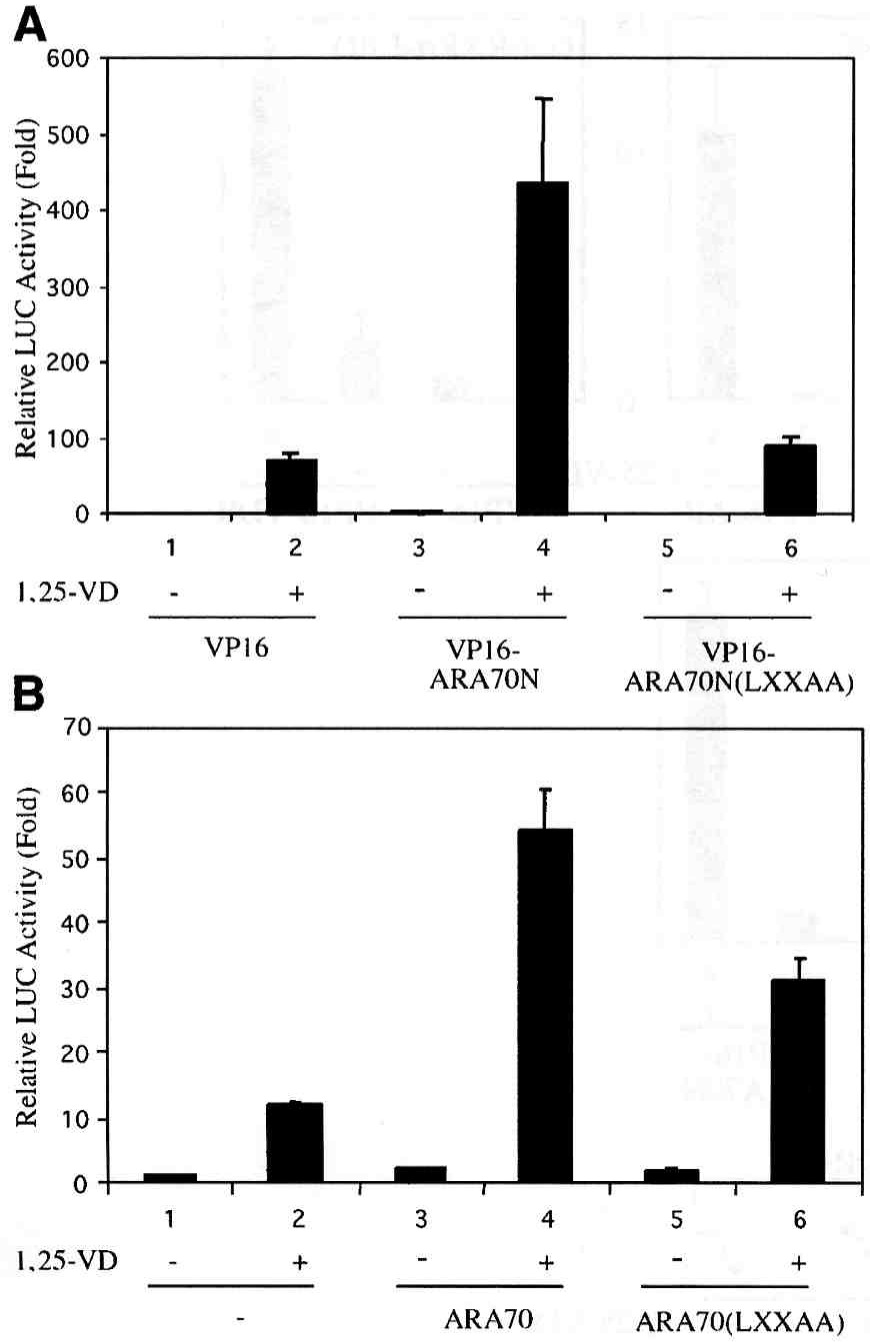

Fig. 5. The interaction and coactivator activity of ARA70 mutant to VDR were analyzed in mammalian two-hybrid and reporter assays. (A) COS-1 cells were plated at a density of $3 \times 10^{4}$ cells/ well in 24-well plates. After $24 \mathrm{~h}$, the mammalian two-hybrid assay was performed by co-transfection of plasmids expressing $0.2 \mu \mathrm{g}$ Gal-VDR, with $0.2 \mu \mathrm{g}$ VP16, VP16-ARA70, or VP16ARA70(LXXAA), with $0.1 \mu \mathrm{g}$ pG5-LUC, and $2.5 \mathrm{ng}$ phRL-tk. After $20 \mathrm{~h}$, cells were treated with EtOH or $10^{-7} M 1,25$-VD for another $24 \mathrm{~h}$, and were then harvested for the LUC assay. The LUC activity relative to lane 1 was calculated and the mean \pm SD of three independent experiments is shown. (B) COS-1 were plated and transfected with $62.5 \mathrm{ng}$ pSG5-VDR, $125 \mathrm{ng}$ prCYP24LUC, $2.5 \mathrm{ng}$ phRL-tk, and 312.5 ng pSG5, pSG5-ARA70, or pSG5ARA70(LXXAA). Cells were then treated and harvested for LUC assay as described in $\mathbf{A}$.

sion of mutated ARA70 containing LXXAA motif in vitamin D-responsive reporter gene assay showed that coactivation of VDR was significantly reduced compared to wildtype ARA70 (Fig. 5B). However, the mutant ARA70 did not completely lose its coactivation function, which implies another interaction domain is located in the $\mathrm{C}$-terminus of ARA70 that may still interact with VDR. These results indicate that the LXXLL motif in ARA70 is important for interaction with VDR and for co-activation of VDR.

\section{Overexpression of ARA70 Restores \\ VDR Transactivity Suppressed by Androgen}

The fact that both VDR and AR can interact with ARA70 indicates the cross-talk between these two receptors may be mediated by competing for ARA70. We tested whether we could overexpress sufficient amounts of ARA70 for VDR transactivation even in the presence of androgen. Different amounts of plasmids encoding ARA70 protein were transfected into LNCaP where androgen treatment suppressed VDR transactivity (Fig. 1B). The androgen-suppressed VDR transactivity was dose-dependently restored by increasing the transfected amount of ARA70 plasmids (Fig. 6). However, ARA54, which promoted VDR through an indirect mechanism, could not restore VDR transactivity suppressed by androgen. Therefore, androgen treatment did not prevent ARA54 from promoting VDR transactivity, but did squelch ARA70 from interacting with VDR, hence decreasing VDR transactivity.

\section{Discussion}

The finding that androgen-AR signal can attenuate VDR transactivation led us to investigate whether AR coregulators can interact with VDR and enhance VDR transactivation. The interaction between AR coregulators and VDR suggests the cross-talk between AR and VDR is mediated by shared coregulators. The interaction between ARA70 and VDR implies that AR and VDR could be linked together by ARA70, or that they may compete for binding to ARA70. Most coregulators utilize the LXXLL sequence motifs to associate with steroid receptors, while AR coregulators also utilize a unique motif, $\operatorname{FXXLF}(12,13)$. Interestingly, these two motifs co-exist in ARA70, implying that AR and another steroid receptor may associate with ARA70 without competing with each other. Further investigation showed that VDR associates with ARA70 through the LXXLL motif, but not the FXXLF motif (data not shown). Our result showing that VDR transactivity suppressed by androgen was restored by overexpression of ARA70 indicates that the competition for association with ARA70 between VDR and AR mediates this cross-talk. Another AR coregulator, ARA54, also enhances VDR transactivity, but no direct interaction between these two proteins was observed in either the mammalian two-hybrid or GST pull-down assay. A recent study has shown that ARA54 may act as a Ub-ligase (E3) and exert proteasome function (14). Therefore, the degradation of VDR partners may be regulated by ARA54, an effect that indirectly modulates VDR transactivity. This mechanism may exist in spite of no direct interaction with VDR. Because androgen signals did not squelch ARA54 from promoting VDR transactivity, the overexpression of ARA54 could not restore VDR transactivity in the presence of androgen.

This observation also suggests that the context of AR and AR coregulators in cells can contribute to how androgenAR affects the vitamin D-VDR signaling. Among all the co- 


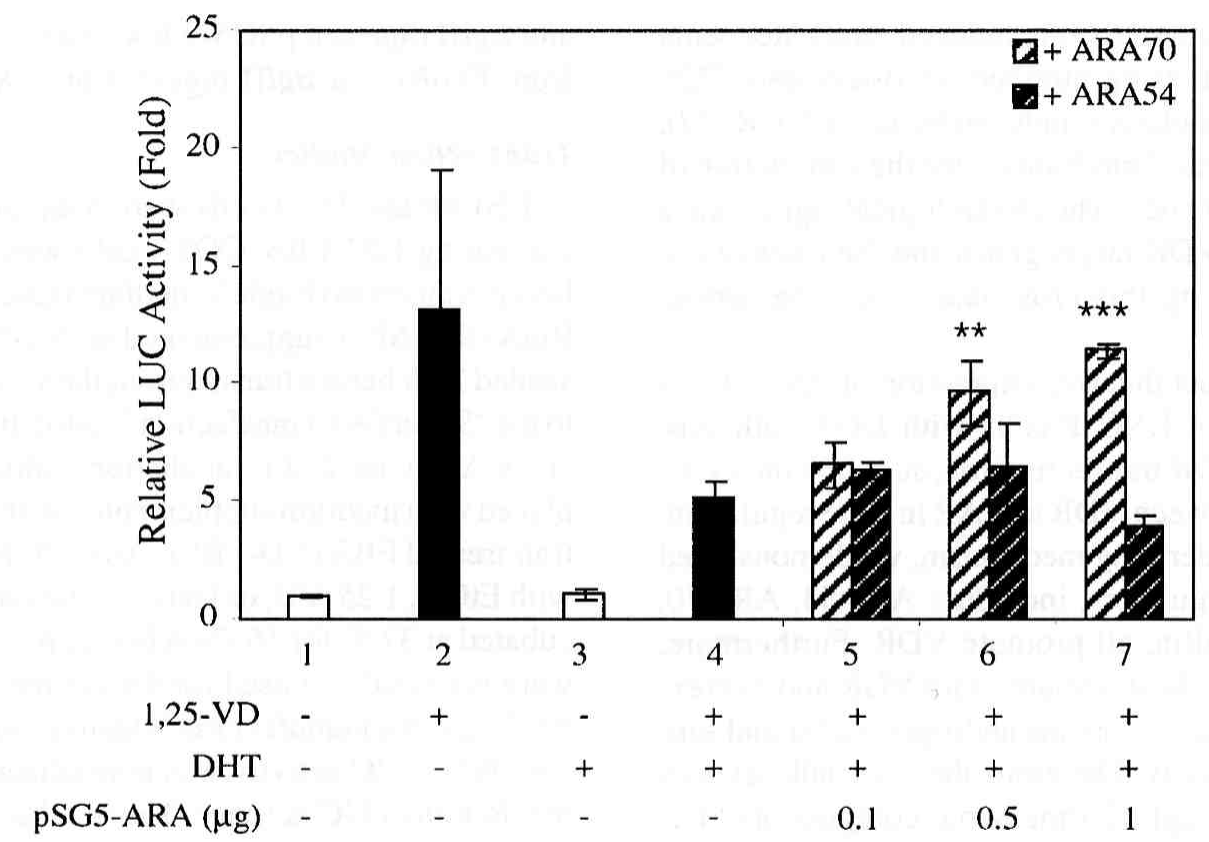

Fig. 6. The dose-dependent effects of ARA70 in restoring VDR transcriptional activity suppressed by androgen signal. LNCaP cells were plated as described in Fig. 1. The amount of plasmids encoding coregulators ranging from $0.1,0.5$, to $1 \mu \mathrm{g}$ were transfected. Total amount of transfected plasmids was adjusted to $1 \mu \mathrm{g} /$ well by empty vector. After 2-3 h incubation, cells were allowed to recover with CD-FBS supplemented medium overnight. Cells were then incubated with EtOH, $10^{-7} M 1,25-\mathrm{VD}$ or/and $10^{-8} M \mathrm{DHT}$. After $24 \mathrm{~h}$, cell lysates were prepared and used for LUC assay. The LUC activity relative to lane 1 was calculated and the mean \pm SD of three independent experiments is shown. ${ }^{*} p<0.01 ; * * p<0.005$ significant differences compared to lane 4 .

activators we tested, only some show the enhancing effect. In fact, ARA55 did not promote VDR transactivation (data not shown). The order of promoting capacity is SRC-1 > ARA70 > supervillin > gelsolin > ARA54 (Fig. 3). Some studies report the overexpression of coregulators, including SRC-1 and gelsolin, in hormone-refractory PCa. This implies enhanced VDR transactivity, hence the reponse to vitamin D may occur in hormone-refractory PCa. More studies are needed to characterize the expression levels of other coregulators in various stages of PCa. Nonetheless, one report demonstrated that $31 \%$ of hormone-refractory tumors contained AR gene amplification (15). Increased expression of AR during PCa progression may result in suppressed VDR activity and diminished antiproliferation effects of vitamin D in higher-grade PCa patients. The composition of $\mathrm{AR}$ and coregulators in cells provides an environment where VDR activity is affected. Therefore, when evaluating the antiproliferation effect of vitamin $D$ in prostate cancer, the impact from overexpression of AR and coregulators should both be considered.

Several studies demonstrate the antiproliferation effect of vitamin $\mathrm{D}$ in androgen-responsive $\mathrm{PCa} \mathrm{LNCaP}$ cells is dependent on functional AR. First, the expression of AR is induced by $1,25-\mathrm{VD}$ and this induction correlates with growth inhibition effect of $1,25-\mathrm{VD}(16)$. Second, anti-androgen treatment attenuates the growth-inhibitory effect of 1,25 VD in LNCaP cells (16). Third, AR RNAi depleted AR ex- pression results in less growth inhibitory effect of 1,25 -VD (17). However, antiandrogen did not affect the anti-proliferation effect of 1,25-VD in androgen-refractory PCa cell lines, MDA PCa, and LNCaP-104R1 $(4,18)$. Overexpression of AR in ALVA 31 did not restore the response to 1,25VD (18). Those results indicate that 1,25-VD no longer depends on AR signaling for growth inhibition in these cell lines. The dilemma that $1,25-\mathrm{VD}$ inhibits $\mathrm{PCa}$ growth through functional AR while functional AR suppress VDR transactivity complicates the outcome from the cross-talk between VDR and AR. Therefore, whether the functional AR affected VDR transactivity can be translated into the antiproliferation effect of 1,25-VD may depend on how cells rely on androgen-AR signal for growth.

In addition to PCa cells, VDR is widely expressed and functions in many tissues, such as parathyroid gland, bone, skin, and intestine (19). The fact that AR coregulators modulate VDR suggests that AR can suppress VDR activity by competing for the same coregulators in common target tissues of VDR and AR, such as the hair follicle and bone. Androgenetic alopecia occurring in men is androgen-dependent, and androgen-regulated factors secreted from dermal papilla cells are believed to inhibit the growth of components of the hair follicle (20). Because alopecia also occurs in VDR knockout mice, the androgenetic alopecia might result from the suppression of VDR activity by androgen signals in the hair follicle (21). In addition, the bone volume 
in AR knockout mice (ARKO) is reduced, and osteopenia may result from increasing numbers of osteoclasts (22). The formation of osteoclasts is induced by active VDR (23), which implies a potential mechanism for the stimulation of osteoclasts in ARKO mice. The physiological significance of AR signaling on VDR target genes and the roles of coregulators in mediating this cross-talk should be further investigated.

In summary, the fact that overexpression of AR in PC-3 cells and treatment of LNCaP cells with DHT both suppress endogenous VDR transactivation, supports the existence of cross-talk between VDR and AR in gene regulation. To investigate the underlying mechanism, we demonstrated that several AR coregulators, including ARA54, ARA70, gelsolin, and supervillin, all promote VDR. Furthermore, ARA70, but not ARA54, associates with VDR and overexpression of ARA70 can restore the androgen-AR signal suppressed VDR transactivity. Therefore, the cross-talk between VDR and AR is through sharing same coregulators. The altered composition of AR and AR coregulators, which frequently occurs during PCa progression, may contribute to 1,25-VD resistance in PCa. This cross-talk could possibly exist in other tissues and further studies are required to elucidate the physiological significance resulting from the interplay between androgen signal, androgen coregulators, and 1,25 -VD signals.

\section{Materials and Methods}

\section{Plasmids}

prCYP24-LUC was constructed by inserting the fragment containing $-950 \mathrm{bp}--55 \mathrm{bp}$ region of rCYP24 promoter released from rat 25-hydroxyvitamin $\mathrm{D}_{3}$ 24-hydroxylase gene promoter CAT construct $(-2.2 \mathrm{~kb}-+188 \mathrm{bp})$, a kind gift from Dr. Yoshihiko Ohyama (Hiroshima University, Japan), by MscI and SacI into SacI and SmaI sites of pGL3TK (a gift from Dr. Eungseok Kim, University of Rochester, Rochester, NY). The cDNA encoding full-length VDR was amplified by PCR and inserted into the pCMX-VP16 vector and pCMX-Gal4.N vector to generate the VP16VDR and Gal4-VDR expression plasmids. pCMV-Gal4ARA54C (amino acids 361-474), pCMV-Gal4-retinoid $x$ receptor $\alpha(\mathrm{RXR} \alpha)$-ligand binding domain (LBD), and pG4AB1-hAR(DE) (amino acids 624-918) were used for expression of Gal4-DNA binding domain (DBD)-conjugated proteins. The plasmids pCMX-VP16-ARA70N (amino acids 1-401) and pCMX-VP16-AR were used to express VP16-conjugated ARA70N and AR full-length proteins. The cDNA encoding the LBD of VDR (VDR-L) was amplified by PCR and inserted into the pGEX-KG vector to generate the GST-VDR-L expression plasmid. The plasmid expressing VP16-conjugated mutant ARA70N (LXXAA) for mammalian two-hybrid, pCMX-VP16-ARA70N(LX XAA), was described previously (24). pSG5-ARA70(LX XAA) was constructed by replacing a fragment from $E c o$ RI and $B g l I I$ digested pSG5-ARA70 with a fragment released from EcoRI and $B g l I I$ digested pCMX-VP16-mtARA70.

\section{Transfection Studies}

LNCaP and PC-3 cells were maintained in RPMI-1640 containing 10\% FBS. COS-1 cells were maintained in Dulbecco's modified Eagle's medium (Life Technologies, Inc., Rockville, MD) supplemented with $10 \%$ FBS. Cells were seeded $24 \mathrm{~h}$ before transfection, then transfected according to the "SuperFect Transfection" instructions (Qiagen, Valencia, CA). After 2-3 h incubation, culture medium was replaced with medium supplemented with $10 \%$ charcoal-dextran treated FBS (CD-FBS). After $20 \mathrm{~h}$, cells were treated with $\mathrm{EtOH}, 1,25-\mathrm{VD}$, or DHT, as indicated, then further incubated at $37^{\circ} \mathrm{C}$ for $16-24 \mathrm{~h}$ before harvesting. Cell lysates were prepared and used for the luciferase (LUC) assay according to the manufacturer's instructions (Promega, Madison, WI). LUC activity was normalized with internal control Renilla-LUC activity. The results were obtained from at least three independent experiments and presented as means $\pm \mathrm{SD}$.

\section{Mammalian Two-Hybrid Assay}

COS- 1 cells were plated at a density of $3 \times 10^{4}$ cells/well in 24-well plates. After $24 \mathrm{~h}$, the mammalian two-hybrid assay was performed by co-transfection of plasmids expressing $0.2 \mu \mathrm{g} \mathrm{Gal4(DBD)-conjugated} \mathrm{receptors} \mathrm{or} \mathrm{ARAs,} 0.2$ $\mu \mathrm{g}$ VP16 alone, VP16 conjugated receptors, or ARAs, 0.1 $\mu \mathrm{g}$ pG5-LUC, and $1 \mathrm{ng}$ pRL-SV40. After $20 \mathrm{~h}$, cells were treated with EtOH, $10^{-8} \mathrm{M} \mathrm{DHT}$, or $10^{-7} M 1,25$-VD for another $24 \mathrm{~h}$, and were then harvested for the LUC assay. The LUC activity represents interaction between receptors and coregulators tested.

\section{Glutathione S-Transferase (GST) Pull-Down Assay}

GST-VDR-L fusion protein, and GST control protein were purified (25). The GST fusion proteins were pulled down by glutathione (GSH) beads at $4^{\circ} \mathrm{C}$ for $1 \mathrm{~h}$ and washed three times with washing buffer. The purified GST fusion proteins and beads were incubated in $100 \mu \mathrm{L}$ binding buffer with $\mathrm{EtOH}$ or $1 \mu M 1,25-\mathrm{VD}$ for $1 \mathrm{~h}$, at $4^{\circ} \mathrm{C}$. In vitro-translated ${ }^{35} \mathrm{~S}$-methionine-labeled RXR, ARA54, and ARA70 full-length proteins were produced using the TNT-coupled reticulocyte lysate system (Promega, Madison, WI). Five microliters of RXR, ARA54, or ARA70 was then added. After incubating for $2 \mathrm{~h}$ at $4^{\circ} \mathrm{C}$, GSH beads were washed with washing buffer three times. Protein complexes were separated by $12 \%$ SDS-PAGE and visualized by Phosphor Imager (Molecular Dynamics Amersham Bioscience, Piscataway, NJ).

\section{Preparation of Cellular Protein and Western Blots}

LNCaP cells were seeded in 100 -mm dishes and treated with ligands. After $24 \mathrm{~h}$, cells were collected and suspended in lysis buffer, and centrifuged. Aliquots corresponding to 
$100 \mu \mathrm{g}$ protein of each sample were loaded onto a $8 \%$ SDSPAGE for Western blotting. After blotting, the membrane was blocked with $5 \%$ nonfat milk and probed with antibody against AR (NH27), VDR (Santa Cruz Biotechnology, Santa Cruz, CA), and actin (Santa Cruz Biotechnology) at a dilution of 1:2000 in PBS containing $0.1 \%$ Tween 20, for $1 \mathrm{~h}$. After washing, the membrane was incubated with the alkaline phosphatase-conjugated anti-rabbit antibody (Santa Cruz Biotechnology) for $45 \mathrm{~min}$, washed again, and the immunoreactive bands were visualized for alkaline phosphatase activity with the 5-bromo-4-chloro-3-indolylphosphate-nitro blue tetrazolium phosphatase substrate (Bio-Rad Laboratories, Hercules, CA).

\section{Acknowledgments}

Expression plasmids of ARA54, ARA70, supervillin, and gelsolin were kindly provided by Dr. Chawnshang Chang (University of Rochester). This work was supported by the Department of Defense grant PC040630.

\section{References}

1. Hansen, C. M., Binderup, L., Hamberg, K. J., and Carlberg, C. (2001). Front Biosci. 6, D820-D848.

2. Johnson, C. S., Hershberger, P. A., and Trump, D. L. (2002). Cancer Metastasis Rev. 21, 147-158.

3. Zhuang, S. H., Schwartz, G. G., Cameron, D., and Burnstein, K. L. (1997). Mol. Cell Endocrinol. 126, 83-90.

4. Zhao, X. Y., Peehl, D. M., Navone, N. M., and Feldman, D. (2000). Endocrinology 141, 2548-2556.

5. Feldman, B. J. and Feldman, D. (2001). Nat. Rev. Cancer 1, 34-45.
6. Gregory, C. W., He, B., Johnson, R. T., et al. (2001). Cancer Res. 61, 4315-4319.

7. Nishimura, K., Ting, H. J., Harada, Y., et al. (2003). Cancer Res. 63, 4888-4894.

8. Lee, Y. F., Lin, W. J., Huang, J., et al. (2002). Cancer Res. 62, 6039-6044.

9. Kang, H. Y., Yeh, S., Fujimoto, N., and Chang, C. (1999). J. Biol. Chem. 274, 8570-8576.

10. Heinlein, C. A. and Chang, C. (2002). Endocr. Rev. 23, 175-200.

11. Ting, H. J., Yeh, S., Nishimura, K., and Chang, C. (2002). Proc. Natl. Acad. Sci. USA 99, 661-666.

12. Hsu, C. L., Chen, Y. L., Yeh, S., et al. (2003). J. Biol. Chem. 278, 23691-23698.

13. He, B., Minges, J. T., Lee, L. W., and Wilson, E. M. (2002). J. Biol. Chem. 277, 10226-10235.

14. Ito, K., Adachi, S., Iwakami, R., et al. (2001). Eur. J. Biochem. 268, 2725-2732.

15. Visakorpi, T. (1999). Ann. Chir. Gynaecol. 88, 11-16.

16. Zhao, X. Y., Ly, L. H., Peehl, D. M., and Feldman, D. (1999). Endocrinology 140, 1205-1212.

17. Bao, B. Y., Hu, Y. C., Ting, H. J., and Lee, Y. F. (2004). Oncogene 23, 3350-3360.

18. Yang, E. S., Maiorino, C. A., Roos, B. A., Knight, S. R., and Burnstein, K. L. (2002). Mol. Cell Endocrinol. 186, 69-79.

19. Christakos, S., Raval-Pandya, M., Wernyj, R. P., and Yang, W. (1996). Biochem. J. 316(Pt 2), 361-371.

20. Trueb, R. M. (2002). Exp. Gerontol. 37, 981-990.

21. Li, Y. C., Pirro, A. E., Amling, M., et al. (1997). Proc. Natl. Acad. Sci. USA 94, 9831-9835.

22. Yeh, S., Tsai, M. Y., Xu, Q., et al. (2002). Proc. Natl. Acad. Sci. USA 99, 13498-13503.

23. Kitazawa, R. and Kitazawa, S. (2002). Biochem. Biophys. Res. Commun. 290, 650-655.

24. Heinlein, C. A., Ting, H. J., Yeh, S., and Chang, C. (1999). J. Biol. Chem. 274, 16147-16152.

25. Rachez, C., Suldan, Z., Ward, J., et al. (1998). Genes Dev. 12, $1787-1800$. 


\section{1 $\alpha, 25$-dihydroxyvitamin $D_{3}$ inhibits prostate cancer cell invasion via modulation of selective proteases}

\author{
Bo-Ying Bao ${ }^{1,2, \dagger}$, Shauh-Der Yeh $^{3, \dagger}$ and Yi-Fen Lee ${ }^{1, *}$ \\ ${ }^{1}$ Department of Urology and ${ }^{2}$ Department of Chemical Engineering, \\ University of Rochester, Rochester, NY 14642, USA and ${ }^{3}$ Graduate Institute \\ of Medical Sciences, Department of Urology, Taipei Medical University, \\ Taipei 110, Taiwan \\ *To whom correspondence should be addressed. Tel: 585275 9702; \\ Fax: 585756 4133; \\ Email: yifen_lee@urmc.rochester.edu
}

Inhibition of invasion and metastasis has become a new approach for treatment of advanced prostate cancer in which secondary hormone therapy has failed. Accumulating evidence indicates that $1 \alpha, 25$-dihydroxyvitamin $D_{3}$ (1,25-VD) suppresses prostate cancer progression by inhibition of tumor growth and metastasis. However, the detailed mechanisms underlying these effects remain to be determined. Here, we used the in vitro cell invasion assay to demonstrate that 1,25-VD inhibits the invasive ability of human prostate cancer cell lines, LNCaP, PC-3 and DU 145. Three major groups of proteases, the matrix metalloproteinases (MMPs), the plasminogen activators (PAs) and the cathepsins (CPs), that are involved in tumor invasion were then examined for changes in activity and expression after 1,25-VD treatment. We found that 1,25-VD decreased MMP-9 and CPs, but not PAs activities, while it increased the activity of their counterparts, tissue inhibitors of metalloproteinase-1 (TIMP-1) and cathepsin inhibitors. Mechanistic studies showed that 1,25-VD did not suppress MMP-9 expression at the transcriptional level, but reduced its mRNA stability. In addition, 1,25-VD increased AP-1 complexes binding to TIMP-1 promoter, which contributed to the enhancement of TIMP-1 activity, and thus resulted in inhibition of MMP activity and tumor invasion. These findings support the idea that vitamin D-based therapies might be beneficial in the management of advanced prostate cancer, especially among patients who have higher MMP-9 and CPs activities.

\section{Introduction}

Prostate cancer is the second leading cause of cancer deaths among North American men. The initial treatment of advanced stage prostate cancer is suppression of testicular androgen production by medical or surgical castration, but nearly all patients develop disease progression. Hormone refractory prostate cancer (HRPC) remains a challenge in the

Abbreviations: 1,25-VD, $1 \alpha, 25$-dihydroxyvitamin $\mathrm{D}_{3}$; CP, cathepsin; CPI, cathepsin inhibitor; ECM, extracellular matrix; HRPC, hormone refractory prostate cancer; MMP, matrix metalloproteinase; PA, plasminogen activator; PAI, plasminogen activator inhibitor; TIMP, tissue inhibitors of metalloproteinase; tPA, tissue PA; TPA, 12-O-tetradecanoylphorbol-13acetate; uPA, urokinase PA.

${ }^{\dagger}$ These authors contributed equally to this work. management of prostate cancer patients. Since no therapy has yet demonstrated a definitive survival advantage, the need for more options in the treatment of HRPC is obvious.

Inhibition of invasion and metastasis might be a good approach for treatment of HRPC in which hormone therapy has failed. Cancer cell metastasis is a step-wise process that includes detachment of cells from the primary tumor, local proteolysis of the basement membrane, intravasation, survival in the circulation, arrest in a distant organ, extravasation and invasion into the surrounding tissue and growth (1). Metastasis necessarily involves penetration of the extracellular matrix (ECM) and basement membrane, and is thought to require the action of proteases.

There are three major groups of proteases, the matrix metalloproteinases (MMPs), the plasminogen activators (PAs), and the cathepsins (CPs), known to be involved in tumor invasion. The MMPs are a family of $>20$ zinc-dependent proteases that are capable of degrading the components of the ECM (2,3). Among the MMPs, gelatinase-A (MMP-2) and gelatinase-B (MMP-9) are key enzymes for degrading type IV collagen, a major component of the basement membrane (4,5). Most MMPs are secreted as inactive pro-enzymes and their proteolytic activities are regulated by other proteases or inhibited by specific inhibitors, tissue inhibitors of metalloproteinase (TIMPs). This implies that the balance between MMP and TIMP levels is a critical determinant of the net proteolytic activity. The increased activities of MMP-2 and MMP-9 have been associated with increasing tumor metastases in various human cancers, suggesting an important functional role for these proteases in the metastatic process (6).

The serine proteases urokinase PA (uPA) and tissue PA (tPA) can convert plasminogen to plasmin, which is capable of promoting tumor growth and angiogenesis, degrading the ECM and basement membrane, and activating pro-MMPs (7). PA activity is negatively regulated by plasminogen activator inhibitors (PAIs), PAI-1 and PAI-2. PAIs function by direct binding to uPA and tPA, and subsequently form inactive complexes (8). Over-expression of uPA and its cell surface receptor (UPAR), along with high PA activity are correlated positively with both the invasive activity of cancer cell lines as well as poor patient prognosis $(9,10)$.

Increased CPs activity and expression, and changes in localization have been observed in many different cancers (11-15). CPs can also degrade components of the ECM, suggesting that these proteases are involved in cancer cell invasion and metastasis (16-18). CPs activities are down-regulated by endogenous inhibitors, such as cystatins. Loss of expression and activity of certain members of the cystatin superfamily have been shown to correlate with the metastatic ability of some cancer cells (19-21).

Epidemiological evidence suggests that low exposure to sunlight and vitamin D deficiency might be risk factors for prostate cancer mortality $(22,23)$. Much research has focused on $1,25-\mathrm{VD}$, the active metabolite of vitamin $\mathrm{D}$, and its ability 
to induce either apoptosis or differentiation in many cancer cells. However, little is known about how 1,25-VD regulates cancer cell invasion and metastasis. In vitro, 1,25-VD has been demonstrated to inhibit the invasion of a number of cultured cancer cells through Matrigel or Amgel, including breast, prostate and lung cancer cells (24-26). In vivo, intravesical instillation of $1,25-\mathrm{VD}$ inhibited the invasion in $N$-methylnitrosourea-induced bladder cancer in rats (27). In a Phase II study, weekly high-dose vitamin D and docetaxel resulted in significant reduction of prostate-specific antigen, increased patients' quality of life, and delayed the time of disease progression in men with metastatic androgenindependent prostate carcinoma $(28,29)$. Regarding mechanisms, 1,25-VD has been shown to inhibit certain proteases, such as some components of the PA and MMP systems, which are important determinants of tumor invasion. Decreased activity of UPA and TPA and increased activity of PAI in response to 1,25-VD have been described in MDA-MB-231 human breast cancer cells (30). In addition, a 1,25-VDresponsive region was identified between nucleotides -2350 and -1870 of the uPA promoter. Decreased activity of MMP-2 and MMP-9 in breast and prostate cancer cells after 1,25-VD treatment have also been demonstrated $(25,30)$.

In this study, we focus on how 1,25 -VD modulates the activities of proteases and their inhibitors to inhibit prostate cancer invasion. We systematically examined the activity and gene expression levels of three major groups of proteases, the MMPs, the PAs and the CPs, after 1,25-VD treatment. We found that the activity of MMP-9 and CPs, but not PAs, decreased and that the activities of their counterparts, TIMP-1 and cathepsin inhibitors (CPIs), increased after 1,25VD treatment. In addition, we have provided a mechanism of how 1,25-VD up-regulates TIMP-1 and down-regulates MMP-9 activity to influence cancer cell invasion. Our results support the idea that vitamin D-based therapeutics are beneficial and may lead to the design of better combination therapies in the management of advanced prostate cancer.

\section{Materials and methods}

Cells, plasmids and materials

1,25-VD was the gift from Dr Lise Binderup of Leo Pharmaceutical Products, 12-O-tetradecanoylphorbol-13-acetate (TPA) was purchased from Sigma and MMP-9 promoter construct was kindly provided by Dr Yasuyuki Sasaguri from University of Occupational and Environmental Health, Japan. AP-1 and NF- $\mathrm{KB}$ reporter constructs were kindly provided by Dr Andrew M.-L.Chan from Mount Sinai School of Medicine, NY. TIMP-1 promoter constructs were kindly provided by Dr Ian M.Clark from University of East Anglia, UK. The LNCaP, PC-3 and DU 145 cells were obtained from the American Type Culture Collection. Cell culture media (RPMI-1640) was obtained from Gibco BRL.

Cell culture, transfection and luciferase assays

LNCaP, PC-3 and DU 145 cells were maintained in RPMI-1640 containing penicillin $(100 \mathrm{IU} / \mathrm{ml})$, streptomycin $(100 \mathrm{mg} / \mathrm{ml})$ and $10 \%$ fetal bovine serum (FBS) at $5 \% \mathrm{CO}_{2}$ and $37^{\circ} \mathrm{C}$. Transfections were performed by using SuperFect according to the manufacturer's suggested procedures (Qiagen). After transfection, cells were treated for $24 \mathrm{~h}$ with charcoal-stripped FBS medium containing either ethanol vehicle or ligands. Cell lysates were prepared, and the luciferase activity was normalized for transfection efficiency using pRL-CMV as an internal control. Luciferase assays were performed using the dualluciferase reporter system (Promega, Madison, WI).

Invasion assay

LNCaP, PC-3 and DU 145 cells were incubated with ethanol vehicle or $100 \mathrm{nM}$ $1,25-\mathrm{VD}$ for $72 \mathrm{~h}$ in regular medium. Cells were harvested and counted, and $5 \times 10^{4}$ cells/chamber were used for each invasion assay. Cells were added to Matrigel coated inserts (Becton Dickinson Labware, Bedford, MA) in serum-free media containing ethanol vehicle or $100 \mathrm{nM} \mathrm{1,25-VD.} \mathrm{The} \mathrm{lower}$ chambers contained medium with $10 \%$ FBS and ethanol vehicle or $100 \mathrm{nM}$ 1,25 -VD. The chambers were incubated for $22 \mathrm{~h}$ at $37^{\circ} \mathrm{C}$. The cells that had invaded to the lower surface of the membranes were fixed and stained with $1 \%$ Toluidine blue, and total invading cell number in five random fields was counted under a light microscope.

\section{Cell attachment assay}

LNCaP, PC-3 and DU 145 cells were incubated with ethanol vehicle or $100 \mathrm{nM}$ 1,25 -VD for $72 \mathrm{~h}$ in regular medium. Cells were harvested and seeded in 24-well tissue culture plates at a density of $5 \times 10^{4}$ cells/well in RPMI-1640 containing $10 \% \mathrm{FBS}$. After incubation for $1 \mathrm{~h}$ at $37^{\circ} \mathrm{C}$, the cells were rinsed gently with phosphate-buffered saline (PBS) and incubated with serum-free medium containing MTT $(0.5 \mathrm{mg} / \mathrm{ml})$ for another $1 \mathrm{~h}$. The absorbance was recorded.

\section{MMP-9 activity assay}

LNCaP, PC-3 and DU 145 cells were incubated with ethanol vehicle or 1,25 VD under serum-free conditions for $48 \mathrm{~h}$, and then conditioned media was collected and normalized with cell number. For measuring MMP-9 activity in cell-conditioned medium, we used the 'MMP-9 biotrak activity assay system' by Amersham Pharmacia (RPN 2634) according to the manufacturer's instructions.

\section{Gelatin substrate gel zymography}

LNCaP, PC-3 and DU 145 cells were incubated with ethanol vehicle or 1,25 VD under serum-free conditions for $48 \mathrm{~h}$, and then conditioned media was collected and normalized with cell number. To analyze the MMP-2, MMP-9 and TIMPs activities in cell-conditioned medium, regular gelatin zymography and reverse gelatin zymography were used. Briefly, samples were subjected to $12 \%$ SDS-PAGE, under non-reducing conditions, in gels co-polymerized with $0.1 \%$ gelatin for gelatin zymography or $0.1 \%$ gelatin plus $40 \mathrm{ng} / \mathrm{ml}$ MMP-2 and MMP-9 (Chemicon International) for reverse gelatin zymography. Following electrophoresis, gels were washed twice for $30 \mathrm{~min}$ in wash buffer (50 M Tris/pH 7.4 and $2.5 \%$ Triton X-100), then rinsed in incubation buffer [50 mM Tris/pH 7.4, $150 \mathrm{mM} \mathrm{NaCl}, 10 \mathrm{mM} \mathrm{CaCl}_{2}$ and $0.02 \% \mathrm{NaN}_{3}$ ] and incubated at $37^{\circ} \mathrm{C}$ for $24 \mathrm{~h}$. Enzyme activities were visualized by staining with Coomassie blue.

\section{Plasminogen activator activity assay}

LNCaP, PC-3 and DU 145 cells were incubated with ethanol vehicle or 1,25VD under serum-free conditions for $48 \mathrm{~h}$, and then conditioned media was collected and analyzed by the PA activity assay. PA activity was measured using the chromogenic substrate S-2251 (H-D-Val-Leu-Lys- $p$-nitroanilide) (31). In brief, plasminogen is converted into plasmin by plasminogen activator, and the generated plasmin hydrolyzes S-2251 to release $p$-nitroaniline. The released $p$-nitroaniline is measured by absorbance at $405 \mathrm{~nm}$. The assay solution was prepared by mixing $20 \mu \mathrm{l}$ of $1 \mathrm{mg} / \mathrm{ml}$ purified bovine plasminogen and $80 \mu \mathrm{l}$ of $1 \mathrm{mM} \mathrm{S}-2251$ in dilution buffer [0.05 M Tris- $\mathrm{HCl}$ (pH 7.4) and $0.1 \mathrm{M} \mathrm{NaCl}$. To determine the total PA activity in each sample, an equal volume of the assay solution was added to $100 \mu l$ of the sample. Following incubation at $37^{\circ} \mathrm{C}$ for $1 \mathrm{~h}$, the absorbance at $405 \mathrm{~nm}$ was measured with a microplate photometer, and normalized to the protein concentration.

\section{$C P$ and CPI activity assays}

LNCaP, PC-3 and DU 145 cells were incubated with ethanol vehicle or 1,25 VD under serum-free conditions for $48 \mathrm{~h}$, and then cell lysates were collected and analyzed by the CP and CPI activity assay. Specific catalytic activity of total proteases was determined fluorometrically by hydrolysis of $500 \mu \mathrm{M}$ synthetic substrate Z-phe-arg-NMec (32). Proteases activity in cell lysates was measured using Z-phe-arg-NMec as substrate in buffer consisting of $250 \mathrm{mM}$ sodium acetate/pH 5.4, $40 \mathrm{mM}$ acetic acid, $2.5 \mathrm{mM}$ EDTA and $1 \mu \mathrm{M}$ DTT. Total CP activity was abolished with $1.53 \mathrm{mM}$ cysteine proteinase inhibitor E-64, therefore activities of CPs were differentiated by inactivation with E-64. Fluorescence was measured in a SPECTRAmax GEMINI spectrofluorometer at an excitation wavelength of $370 \mathrm{~nm}$ and an emission wavelength of $460 \mathrm{~nm}$.

Total CPI activity was measured by incubating cell lysates with the cysteine proteinase papain as follows. Samples were boiled for $5 \mathrm{~min}$ to denature heatsensitive proteins such as the CPs; CPIs are heat stable (33). The denatured proteins were removed by centrifugation at $14000 \times$ r.p.m. for $10 \mathrm{~min}$ at $4^{\circ} \mathrm{C}$. Aliquots of the sample were incubated with $10 \mu \mathrm{l}$ of $10 \mathrm{mM}$ papain and remaining papain activity was measured essentially as described for CP activity assay using Z-phe-arg-NMec as substrate. Total papain activity was determined in assays containing aliquots of PBS. 
Real-time PCR analysis

LNCaP, PC-3 and DU 145 cells were cultured and treated with either ethanol vehicle or $100 \mathrm{nM}$ 1,25-VD for 12, 24 and $48 \mathrm{~h}$, then total RNA was extracted using Trizol (Invitrogen). We carried out reverse transcription with the Super Script II kit (Invitrogen) and PCR amplifications with SYBR Green PCR Master Mix on an iCycler IQ multi-color real-time PCR detection system (Bio-Rad). The PCR was performed as follows: initial denaturation at $95^{\circ} \mathrm{C}$ for $10 \mathrm{~min}$, and 45 cycles of denaturation at $95^{\circ} \mathrm{C}$ for $30 \mathrm{~s}$, annealing at $61^{\circ} \mathrm{C}$ for $30 \mathrm{~s}$ and extension at $72^{\circ} \mathrm{C}$ for $30 \mathrm{~s}$. Primer sequences were MMP-2, sense $5^{\prime}$-CAAGGAGTACAACAGCTGCACTGATA-3' and anti-sense 5'-GGTGCAGCTCTCATATTTGTTGC-3' (34); MMP-9, sense $5^{\prime}$-TGGGCAAGGGCGTCGTGGTTC-3' and anti-sense $5^{\prime}$-TGGTGCAGGCGGAGTAGGATT$3^{\prime}$ (34); TIMP-1, sense $5^{\prime}$-TCAACCAGACCACCTTATAC- $3^{\prime}$ and anti-sense 5'-ATTCCTCACAGCCAACAG-3'; TIMP-2, sense 5'-GTAGTGATCAGGGCCAAAG- $3^{\prime}$ and anti-sense 5'-TTCTCTGTGACCCAGTCCAT-3' (35); tPA, sense $5^{\prime}$-ATGACACTTACGACAATG- $3^{\prime}$ and anti-sense $5^{\prime}$-GGTGACTGTTCTGTTAAG-3'; uPA, sense $5^{\prime}$-CACGCAAGGGGAGATGAA- $3^{\prime}$ and anti-sense $5^{\prime}$-ACAGCATTTTGGTGGTGACTT-3' (36); uPAR, sense $5^{\prime}$ CAACGACACCTTCCACTTC- $3^{\prime}$ and anti-sense $5^{\prime}$-GCACAGCCTCTTACCATATAG- $3^{\prime}$; PAI-1, sense $5^{\prime}$-GCTGGTGCTGGTGAATGC- $3^{\prime}$ and antisense $5^{\prime}$-GGCGTGGTGAACTCAGTATAG-3'; PAI-2, sense 5'-CCAGAGAACAACCAGATTG-3' and anti-sense 5'-AGAGCGGAAGGATGAATG$3^{\prime}$; CP B, sense 5'-TGTGTATTCGGACTTCCTGCT- $3^{\prime}$ and anti-sense $5^{\prime}$ GTGTGCCATTCTCCACTCC-3' (37); CP H, sense 5'-CAACAATGGGAACCACACAT- $3^{\prime}$ and anti-sense 5'-GCAAAGCTCACAGGGTTGTA-3' (38); CP L, sense 5'-CAGTGTGGTTCTTGTTGGGCT-3' and anti-sense $5^{\prime}$ CTTGAGGCCCAGAGCAGTCTA-3' (39); Cystatin A, sense 5'-CCAAACCCGCCACTCCAGAAATC- $3^{\prime}$ and anti-sense $5^{\prime}$-CAGTAGCCAGTTGAAGGAATCAGAACAC-3'; Cystatin M, sense 5'-CAGCAACAGCATCTACTAC- $3^{\prime}$ and anti-sense $5^{\prime}$-ACCACAAGGACCTCAAAG- $3^{\prime} ; \beta$-actin, sense $5^{\prime}$-TGTGCCCATCTACGAGGGGTATGC-3' ${ }^{\prime}$ and anti-sense 5'-GGTACATGGTGGTGCCGCCAGACA-3'. The quantification of each sample relative to control sample was calculated using $2^{-\Delta \Delta C T}$ method (40). The expected sizes and the absence of non-specific amplification products were confirmed by agarose gel electrophoresis and melting curve analysis.

MMP-9 mRNA stability assay

PC-3 cells were pre-treated with ethanol vehicle or $100 \mathrm{nM} 1,25-\mathrm{VD}$ for $48 \mathrm{~h}$ and then incubated with actinomycin D $(5 \mu \mathrm{g} / \mathrm{ml})$ for $2,4,8$ and $16 \mathrm{~h}$. Total mRNA was prepared and analyzed by real-time PCR described above.

DNA pull-down assay

Oligonucleotides corresponding to the AP-1 site were synthesized according to published sequences (41). Sequences of the oligonucleotides were as follows: wild-type-AP-1 (-105), sense $\quad 5^{\prime}$-biotin-GATGGTGGGTGGATGAGTAATGCATCCAG- $3^{\prime}$ and anti-sense $5^{\prime}$-CTTCCTGGATGCATTACTCATCCACCCAC-3' (AP-1 site is underlined). For mutant-AP-1 (-105), in which the AP-1 binding site of wild-type-AP-1 (-105) was destroyed, 5'-TGAGTAA- $3^{\prime}$ was mutated into $5^{\prime}$-GGACTAA-3' $(41)$. Double-stranded probes were made by annealing a $50 \mu \mathrm{M}$ mixture of complementary oligonucleotides in TNE (10 mM Tris- $\mathrm{HCl}, 50 \mathrm{mM} \mathrm{NaCl}$ and $1 \mathrm{mM}$ EDTA), heating to $95^{\circ} \mathrm{C}$ for $5 \mathrm{~min}$, and then slowly cooling to room temperature. Nuclear extracts were prepared from PC-3 cells that were serum-starved for $24 \mathrm{~h}$ and stimulated with ethanol vehicle, $100 \mathrm{nM}$ TPA or 1,25-VD for $3 \mathrm{~h}$ (42). For pull-down assays, $30 \mu \mathrm{g}$ of nuclear extracts were incubated in a $25 \mu \mathrm{l}$ reaction mixture consisting of $10 \mu \mathrm{M}$ probe and $1 \times$ binding buffer $\left(4 \%\right.$ glycerol, $1 \mathrm{mM} \mathrm{MgCl}_{2}, 0.5 \mathrm{mM}$ EDTA, $0.5 \mathrm{mM}$ DTT, $50 \mathrm{mM} \mathrm{NaCl}, 10 \mathrm{mM}$ Tris- $\mathrm{HCl} / \mathrm{pH} 7.5$, and $0.05 \mathrm{mg} / \mathrm{ml}$ polydI-dC). After incubation for $30 \mathrm{~min}$ at room temperature, the reaction volume was increased to $0.5 \mathrm{ml}$ with modified binding buffer, which does not contain poly(dI-dC). To capture the complexes, streptavidin-agarose was added, and incubated for $1 \mathrm{~h}$ at $4^{\circ} \mathrm{C}$. The complexes were washed three times with modified binding buffer, and eluted from the beads by the addition of $2 \times$ Laemmli buffer and heating to $95^{\circ} \mathrm{C}$ for $5 \mathrm{~min}$. Proteins were then separated by $10 \%$ SDS-PAGE and analyzed for the c-Jun (SC-44, Santa Cruz) by immunoblot analysis.

\section{Statistical and densitometric analysis}

The results are the mean \pm SD of values obtained from two or three separate experiments. ANOVA was used to analyze protease activity, real-time PCR and luciferase assay data. Data on invasion assay were analyzed by Student's $t$-test to assess the statistical significance of the difference between control and 1,25-VD-treated groups. A statistically significant difference was considered to be present at $P<0.05$. Autoradiograms/bands were scanned and the mean density of each band was analyzed by the Quantity one program (Bio-Rad). Densitometric data presented below bands are the fold changes compared with control sample band densities for each treatment time.

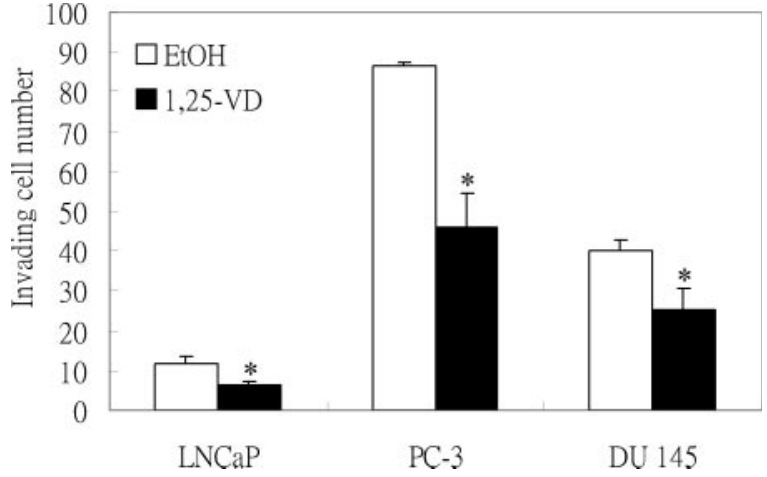

Fig. 1. The anti-invasive effects of $1,25-\mathrm{VD}$ in human prostate cancer cell lines. LNCaP, PC-3 and DU 145 cells were pre-treated with ethanol vehicle or $100 \mathrm{nM} 1,25-\mathrm{VD}$ for 3 days before a $22 \mathrm{~h}$ invasion assay. Cells invading through Matrigel-coated membrane were stained and counted under a microscope. ${ }^{*}$ Indicates significant $(P<0.05)$ differences between control and 1,25-VD-treated groups.

\section{Results}

1,25-VD inhibits human prostate cancer cell invasion in vitro We first explored the vitamin D effect on the prostate cancer cell invasion ability by in vitro matrigel invasion assay as described previously $(25,30)$. We treated cells with 1,25 -VD for 3 days and followed with a $22 \mathrm{~h}$ invasion period. The invasion potentials of three prostate cancer cell lines were determined by counting the invading cells in the lower membrane. As shown in Figure 1, 1,25-VD inhibited LNCaP, PC-3 and DU 145 cells invasion by 43,47 and 38\%, respectively. According to others' and our previous study, 3 days of 1,25 -VD treatment can inhibit LNCaP, but not PC-3 and DU 145 cell proliferation (43-45). In addition to cell proliferation, we also examined 1,25-VD effects on cell attachment, and we found that 1,25 -VD can decrease PC-3 attachment by $5 \%$, but there was no effect on LNCaP or DU 145 cell attachment (data not shown). Therefore, these data suggest that neither decreased cell proliferation nor cell attachment contributes to $1,25-\mathrm{VD}$ anti-invasive effects in prostate cancer cells.

\section{1,25-VD regulates matrix metalloproteinase activities}

The mechanisms underlying the anti-invasive effects of 1,25VD on prostate cancer cells were then examined. We first tested whether 1,25-VD inhibits cell invasion via modulation of MMP activities. MMP-9 activity assay for determining active-MMP-9 activity, gelatin zymography for determining pro-MMP-2 and pro-MMP-9 activities, and reverse gelatin zymography for determining TIMP-1 activities were applied. As shown in Figure 2, treatment of PC-3 and DU 145 cells, but not LNCaP cells, with 1,25 -VD decreased active- and proMMP-9 activity (Figure 2A and B), associated with a concomitant increase in secreted TIMP-1 activity (Figure 2C). We then tested whether the regulation of MMP-9 and TIMP-1 activities by 1,25 -VD occurred directly at the transcriptional level. The mRNA levels of MMP-9 and TIMP-1 were measured by quantitative real-time PCR. As shown in Figure 2D, the endogenous MMP-9 transcripts expressed highest in PC-3, then DU 145, least in $\mathrm{LNCaP}$, which corresponds to the enzyme activity we observed in Figure 2A and B. The MMP-9 transcripts were suppressed by $1,25-\mathrm{VD}$ in all three prostate cancer cell lines we tested in a 1,25-VD treated time-dependent manner. Similar to MMP-9, its counterpart TIMP-1 has a similar 

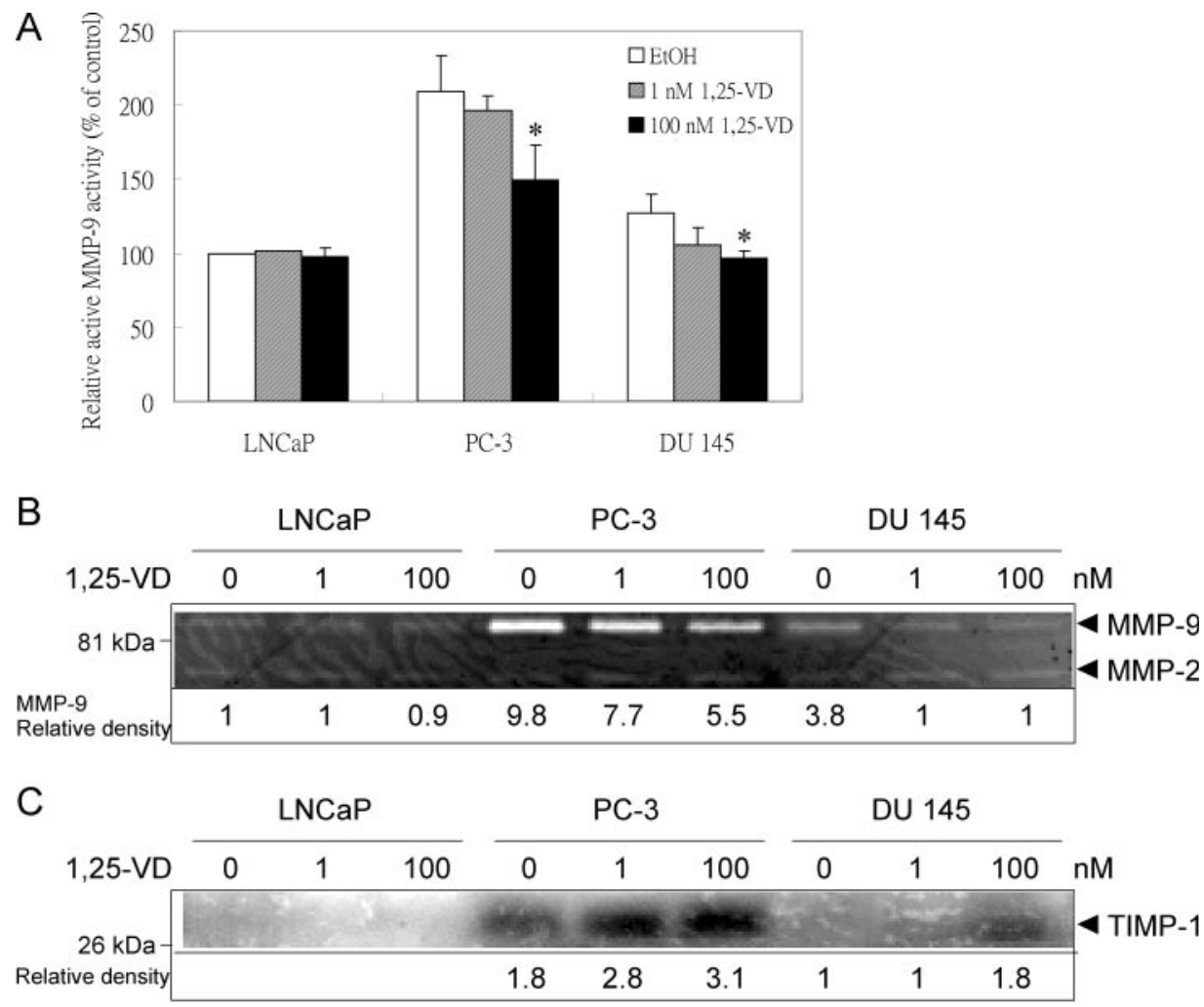

D
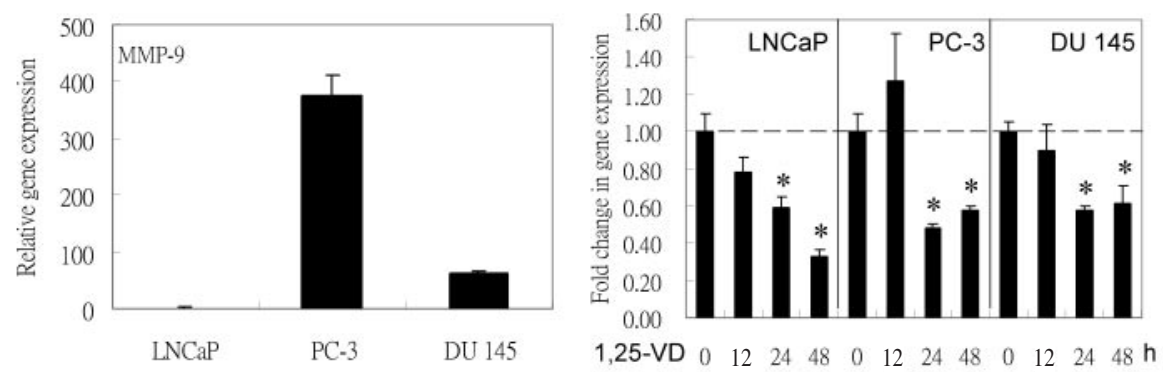

E
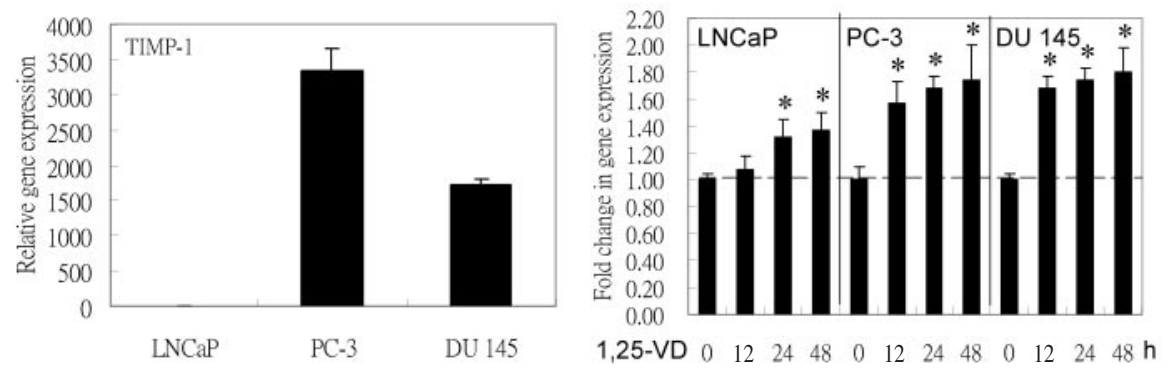

Fig. 2. The effect of 1,25-VD on gelatinolytic matrix metalloproteinase system. Down-regulation of MMP-9 activity (A and B), and up-regulation of TIMP-1 activity (C), by 1,25-VD. LNCaP, PC-3 and DU 145 cells were treated with ethanol vehicle or the indicated concentrations of $1,25-\mathrm{VD}$ for 48 h, and then the secreted MMPs and TIMPs were analyzed separately by MMP-9 activity (A), gelatin zymographic (B), and reverse zymographic (C) assays. The MMP-9 activity from untreated control LNCaP cells were set as $100 \%$ (A). The activity was extrapolated by densitometric analysis and values represent the fold changes relative to untreated control LNCaP for MMP-9 (B), and to DU 145 cells for TIMP-1 (C). (D) The mRNA expression of endogenous MMP-9 (left panel) and 1,25-VD effects on its expression (right panel) in prostate cancer cell lines. (E) The mRNA expression of endogenous TIMP-1 (left panel) and 1,25-VD effects on its expression (right panel) in prostate cancer cell lines. LNCaP, PC-3 and DU 145 cells were cultured and treated with either

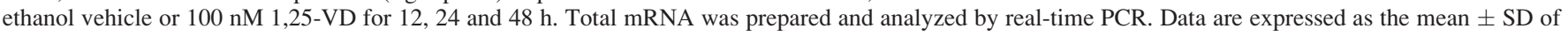
triplicate samples. Values represent the fold changes in gene expression relative to LNCaP cells or untreated control. ${ }^{*}$ Indicates significance $(P<0.05)$.

endogenous expression level among three prostate cancer cell lines. In contrast, when treated with 1,25-VD, TIMP-1 transcripts were induced in a time-dependent manner (Figure 2E), which correlates with the enzyme activities. However, the
mRNA level of MMP-2 was slightly increased and there was no consistent change on TIMP-2 after 1,25-VD treatment (Supplementary Figure 1). In summary, we concluded that 1,25 -VD may inhibit human prostate cancer cell invasion 


\section{A Conditioned media}

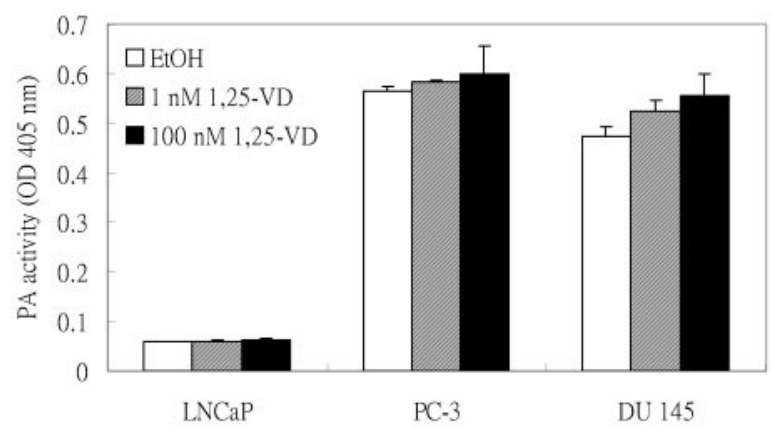

Cell lysates
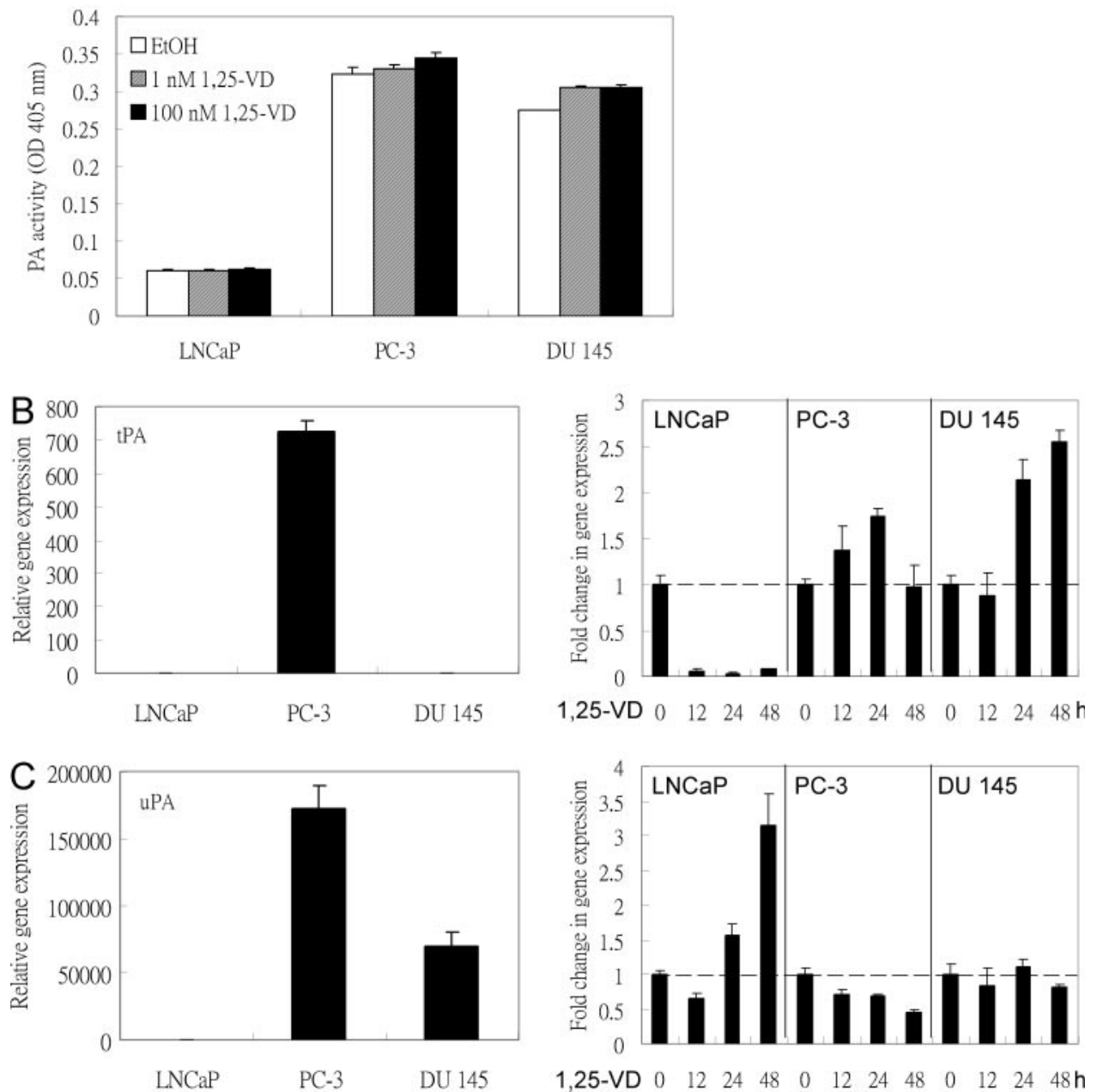

Fig. 3. The effect of 1,25-VD on plasminogen activator system. (A) The effect of 1,25-VD on PA activity. LNCaP, PC-3 and DU 145 cells were treated with ethanol vehicle or the indicated concentrations of 1,25-VD for $48 \mathrm{~h}$, and then conditioned media and cell lysates were analyzed by PA activity assay. (B) The mRNA expression of endogenous tPA (left panel) and 1,25-VD effects on its expression (right panel) in prostate cancer cell lines. (C) The mRNAs expression of endogenous uPA (left panel) and 1,25-VD effects on its expression (right panel) in prostate cancer cell lines. LNCaP, PC-3 and DU 145 cells were cultured and treated with either ethanol vehicle or $100 \mathrm{nM}$ 1,25-VD for 12, 24 and 48 h. Total mRNA was prepared and analyzed by real-time PCR. Data are expressed as the mean $\pm \mathrm{SD}$ of triplicate samples. Values represent the fold changes in gene expression relative to LNCaP cells or untreated control.

through modulation of selective MMP activities, including those of MMP-9 and TIMP-1.

\section{1,25-VD has selective effects on PA and CP systems}

Serine and lysosomal cysteine proteases have been implicated in cancer cell invasion and metastasis, not only in degradation of ECM, but also through activation of many other protease zymogens, including pro-MMP-9. We have shown that 1,25VD inhibits prostate cancer cell invasion by modulating MMP9 and TIMP-1 activities. Therefore, we examined the ability of $1,25-\mathrm{VD}$ to regulate $\mathrm{PA}$ and $\mathrm{CP}$ activities. As shown in Figure 3A, PA activities have no significant change in prostate cancer cell conditioned medium or cell lysates after 1,25-VD treatment. The mRNA expression of molecules involved in the 
PA system, including tPA, uPA, uPAR, PAI-1 and PAI-2 were measured by quantitative real-time PCR. Similar to MMP-9, PC-3 cells express the highest tPA and uPA mRNA; however, 1,25-VD had little or no consistent effect on the expression of PA-related genes among the cell lines tested (Figure 3B and C, and Supplementary Figure 2).

Next, we examined 1,25-VD effects on CP activities. LNCaP, PC-3 and DU 145 cells were treated with increasing concentrations of 1,25-VD for $48 \mathrm{~h}$, and then cell lysates were collected for determination of $\mathrm{CP}$ and $\mathrm{CPI}$ activities. CP L $+\mathrm{B}$ activities were measured using Z-phe-arg-NMec as substrate, which is mainly hydrolyzed by $\mathrm{CP} \mathrm{L}$ and to a small extent by CP B (46). As shown in Figure 4A, 1,25-VD inhibited CP activity in DU 145 cells, but had less effect on LNCaP and PC-3 cells. Total heat-stable CPI was measured, as shown in Figure 4B, 1,25-VD significantly induced CPI activity in all
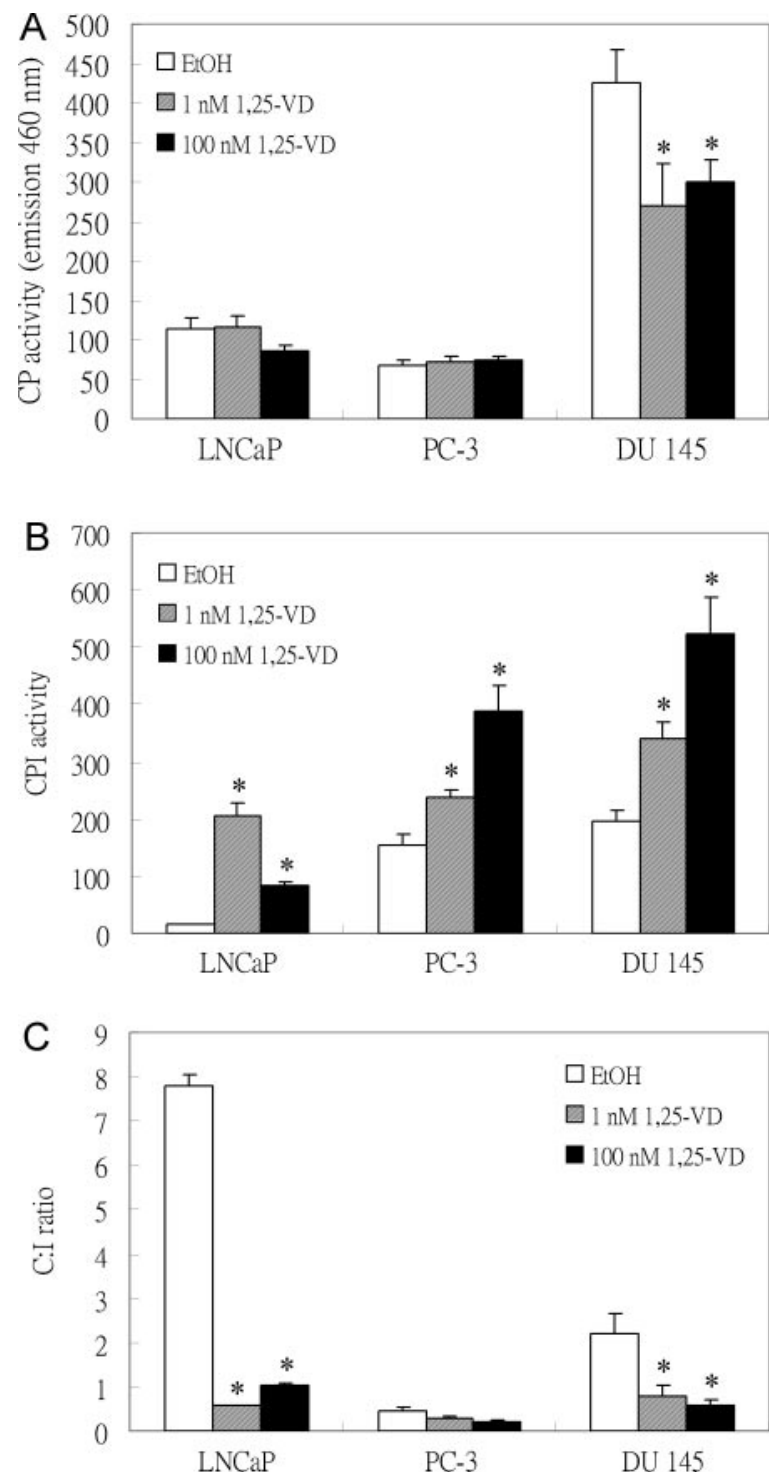

Fig. 4. The effect of 1,25-VD on cathepsin activity. (A) Regulation of CP activity by 1,25-VD in prostate cancer cells. (B) Up-regulation of CPI activity by 1,25-VD in prostate cancer cells. LNCaP, PC-3 and DU 145 cells were treated with the indicated concentrations of 1,25-VD for $48 \mathrm{~h}$, and then cell lysates were analyzed for CP and CPI enzyme activity. (C) Ratio of CP to $\mathrm{CPI}$ activity $(\mathrm{C}: \mathrm{I})$ in prostate cancer cell lines in response to $1,25-\mathrm{VD}$. ${ }^{*}$ Indicates significance $(P<0.05)$. three cell lines we tested. The ratio of CP to CPI activity (C:I ratio), which represents invasion potential, was calculated and shown to decrease in all cell lines (Figure 4C). The mRNA expression level of potential genes involved in regulation of $\mathrm{CP}$ activities, such as $\mathrm{CP} \mathrm{B}, \mathrm{CP} \mathrm{H}, \mathrm{CP} \mathrm{L}$, cystatin $\mathrm{A}$ and cystatin $\mathrm{M}$ were measured. However, there was no significant or consistent change of all those $\mathrm{CP}$-related genes we tested upon 1,25-VD treatment among the cell lines (Supplementary Figure 3). Taken together, we concluded that 1,25-VD might decrease C:I ratio and then consequently inhibit prostate cancer cell invasion, yet the 1,25-VD targets and detailed mechanisms need to be further examined.

The suppression of MMP-9 activity by 1,25-VD was not regulated at the transcriptional level

We have shown in Figure 2 that 1,25-VD inhibited both secreted MMP-9 activity and MMP-9 transcripts in PC-3 and DU 145 cells, so the regulation of MMP-9 by 1,25-VD was then examined using a $1.9 \mathrm{~kb}$ MMP-9 promoter luciferase reporter gene assay in PC-3 cells. As shown in Figure 5A, luciferase activity was induced $\sim 2$.7-fold when cells were treated with ethanol vehicle or $100 \mathrm{nM}$ TPA, however, there was no change when cells were treated with 1,25-VD. AP-1 and NF- $\mathrm{KB}$ have been shown to activate the MMP-9 promoter, therefore we tested whether 1,25-VD modulated MMP-9 activity indirectly through down-regulation of AP-1 or NF- $\mathrm{KB}$ by testing with $\mathrm{AP}-1$ and $\mathrm{NF}-\kappa \mathrm{B}$ responsive DNA element containing luciferase constructs. As shown in Figure $5 \mathrm{~B}$ and $\mathrm{C}$, 1,25-VD had no effect on NF-кB-response element driven luciferase activity, and slightly enhanced AP-1-response element driven luciferase activity, suggesting that the suppression of MMP-9 mRNA expression might not be regulated at the transcriptional level.

To test whether 1,25-VD could affect the posttranscriptional events of MMP-9 mRNA, we performed actinomycin D experiments. PC-3 cells were treated with ethanol or $100 \mathrm{nM}$ 1,25-VD for $48 \mathrm{~h}$ before transcription was blocked by actinomycin $\mathrm{D}$. We found that 1,25-VD increased the decay of MMP-9 mRNA (Figure 5D). In conclusion, these data suggested that 1,25-VD inhibited MMP-9 activity and mRNA expression might result from the decrease of MMP-9 mRNA stability.

\section{Transcriptional up-regulation of TIMP-1 by 1,25-VD}

We have shown in Figure 2 that 1,25-VD induced TIMP-1 mRNA expression and activity, thus the regulation was examined further. As illustrated in Figure 6A, four TIMP-1 promoter constructs that contain three different lengths of promoter, $-1718,-738,-102$ and one AP-1 mutated (mt -102) luciferase reporter were tested in PC-3 cells. As shown in Figure 6B, TPA, serving as a positive control, induced luciferase activity to $\sim 3$-fold, and 1,25-VD activated the TIMP-1 promoter activity in a dose-dependent manner in all lengths of TIMP-1 promoter constructs we tested. Similar results were observed in DU 145 cells (data not shown). However, mutation of AP-1 (mt -102) results in a diminished response to both TPA and 1,25-VD. Therefore, AP-1 might be involved in 1,25-VD-mediated TIMP-1 activation. To further test our hypothesis, AP-1 responsive DNA binding capacity in PC-3 cells was examined, after 1,25-VD treatment, by DNA pull-down assay. Biotin-labeled oligonucleotides corresponding to the AP-1 site in the TIMP-1 promoter were used to pull down the AP-1 complex from TPA or 1,25-VD treated 

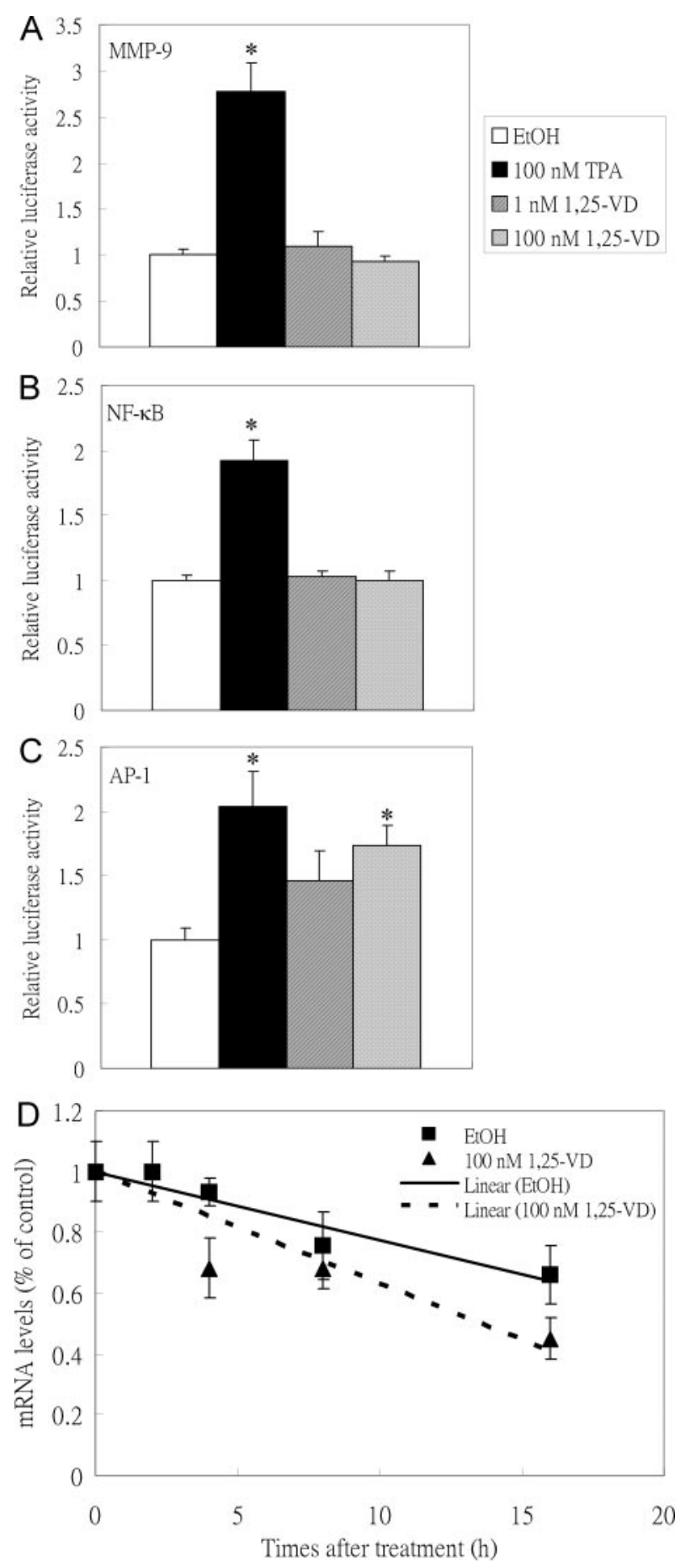

Fig. 5. 1,25-VD has no direct effect on matrix metalloproteinase-9 promoter. Effects of 1,25-VD on the MMP-9 promoter containing luciferase reporter gene activity (A) on NF- $\mathrm{\kappa B}$ response element containing luciferase reporter gene activities (B), and on AP-1 site containing luciferase reporter gene activity (C). PC-3 cells were transiently transfected with $0.8 \mu \mathrm{g} /$ well of MMP-9, NF-кB or AP-1 reporter constructs, and treated with ethanol vehicle, $100 \mathrm{nM}$ TPA, $1 \mathrm{nM}$ or $100 \mathrm{nM}$ 1,25-VD, as indicated, for $24 \mathrm{~h}$. Reporter gene expression was measured via the luciferase assay. The fold induction of luciferase activity is presented relative to the transactivation observed upon vehicle treatment. ${ }^{*}$ Indicates significant $(P<0.05)$ difference between control and TPA- or 1,25-VD-treated groups. (D) Effects of 1,25-VD on MMP-9 mRNA stability in PC-3 cells. PC-3 cells were pretreated with ethanol vehical or $100 \mathrm{nM} 1,25-\mathrm{VD}$ for $48 \mathrm{~h}$ and then incubated with actinomycin D $(5 \mu \mathrm{g} / \mathrm{ml})$ for $2,4,8$ and $16 \mathrm{~h}$. Total mRNA was prepared and analyzed by real-time PCR. The MMP-9 mRNA levels before actinomycin D treatment were set as $100 \%$. Data are expressed as the mean $\pm \mathrm{SD}$ of triplicate samples.
PC-3 nuclear extracts. As shown in Figure 6C, increased amounts of c-Jun proteins, one component of the AP-1 complex, were pulled-down by wild-type-AP-1 DNA when cells were treated with TPA or 1,25-VD (lanes 2 and 3 versus $1)$; however, no c-Jun protein was pulled-down by mt-AP-1 DNA (lanes 4-6). These results indicated that 1,25-VD activated TIMP-1 mRNA expression and its activity through the up-regulation of AP-1 complexes, and the enhancement of TIMP-1 results in, at least partly, inhibition of MMP activity and invasiveness of cancer cells.

\section{Discussion}

There are several steps in tumor progression that could be regulated by $1,25-\mathrm{VD}$. First, $1,25-\mathrm{VD}$ is a potent growth inhibitor for cells of epithelial origin or distal metastasis, and this is achieved by inducing cell cycle arrest, differentiation or apoptosis (47). Second, 1,25-VD reduces tumor metastasis, and this is thought to involve the regulation of proteases $(25,30)$. Third, 1,25-VD has been shown to inhibit neoangiogenesis of cancer cells (48). In this study, we found 1,25-VD decreased cell invasion of three human prostate cancer cell lines, LNCaP, PC-3 and DU 145, to a similar degree by modulating the activity of selective proteases and their corresponding gene expression.

Type IV collagen is a major structural protein in the basement membrane and ECM. A number of studies have linked elevated MMP-2 and MMP-9 levels with an increased tumor metastatic potential. In human prostate cancer cells and mononuclear phagocytes, 1,25-VD has been reported to reduce MMP-9 activity $(25,49)$, which is similar to our results (Figure 2A and B). In our data, we found that 1,25-VD inhibits MMP-9 transcript expression in all three cell lines (Figure 2D), which led us to further dissect the molecular mechanisms underlying this suppression. It is known that the human MMP-9 promoter contains regulatory elements for AP-1 $(-533,-79), \mathrm{NF}-\kappa \mathrm{B}(-600), \mathrm{SP}-1(-558)$ and polyoma enhancer A3 (PEA3) (-540) (50). The expression of MMP-9 is regulated by various growth factors, cytokines and oncogenes, including FGF-2, EGF, HGF, TNF- $\alpha$ and Ras, mainly through binding to AP-1 and NF- $\mathrm{BB}$ binding sites (51-54). $1,25-\mathrm{VD}$ has been reported to inhibit NF- $\mathrm{KB}$ activity in human lymphocytes and fibroblasts by either decreasing NF-кB DNA binding capacity or decreasing the expression of its precursor protein $(55,56)$. Thus, we hypothesized that 1,25 -VD might decrease NF- $\kappa \mathrm{B}$ activity and consequently decrease transcription of MMP-9. However, we failed to show that 1,25-VD decreased the transcriptional activity of $1.9 \mathrm{~kb}$ of the MMP-9 promoter (Figure $5 \mathrm{~A}$ ) or $\mathrm{NF}-\kappa \mathrm{B}$ transcriptional activity (Figure 5B), whereas AP-1 activity was increased (Figure 5C). Therefore, cell-specific factors, other than NF$\kappa \mathrm{B}$, or some post-transcriptional modifications might be involved in 1,25-VD mediated suppression of $M M P-9$ gene transcription in human prostate cancer cells, and such factors have yet to be determined.

Involvement of 1,25-VD in the regulation of the PA system has been reported in human keratinocytes, rat osteogenic sarcoma cells, U-937 mononuclear phagocytes and human breast cancer cells (30,57-59). Down-regulation of uPA by $1,25-\mathrm{VD}$ was found at the transcriptional level in HT-1080 human keratinocytes. The uPA promoter contains SP-1, c-ets-1, cAMP responsive elements and two AP-1 sites (60). Promoter activity analysis of the uPA suggested that the $1,25-\mathrm{VD}$ responsive 

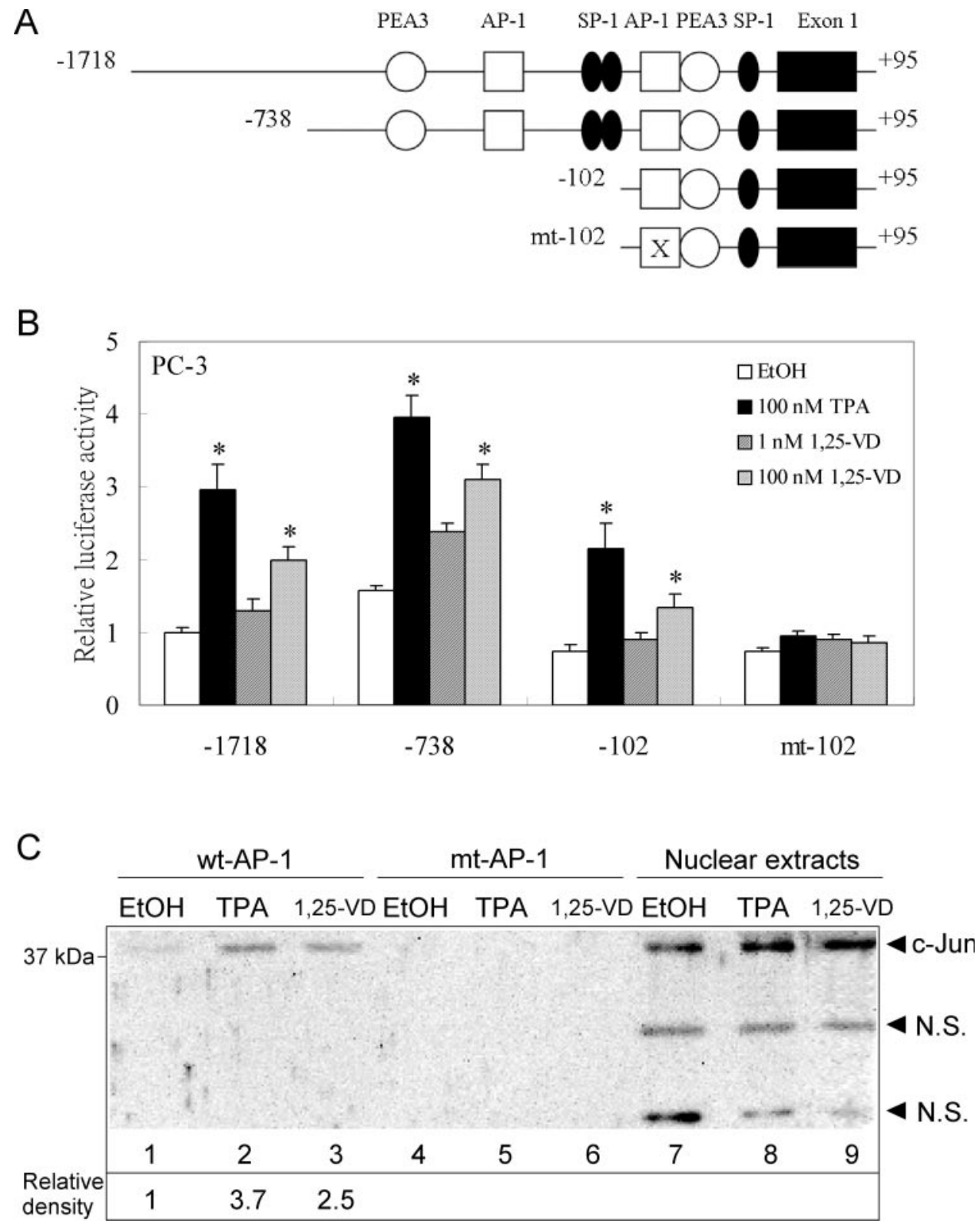

Fig. 6. Regulation of tissue inhibitors of metalloproteinase-1 promoter activity by 1,25-VD. (A) Schematic structure of TIMP-1 promoter constructs used for testing luciferase activity. (B) Effects of $1,25-\mathrm{VD}$ on the activities of TIMP-1 promoter constructs. PC-3 cells were transiently transfected with $0.8 \mu \mathrm{g} / \mathrm{well}$ of different lengths of TIMP-1 reporter constructs, and treated with ethanol vehicle, $100 \mathrm{nM}$ TPA, $1 \mathrm{nM}$ or 100 nM 1,25-VD, as indicated, for 24 h. Reporter gene expression was measured via the luciferase assay. The fold induction of luciferase activity is presented relative to the transactivation observed upon vehicle treatment. ${ }^{*}$ Indicates significant $(P<0.05)$ difference between control and TPA- or 1,25-VD-treated groups. $(\mathbf{C})$ 1,25-VD increases AP-1 DNA binding on the TIMP-1 promoter. Nuclear extracts were prepared from PC-3 cells that were serum-starved for $24 \mathrm{~h}$ and stimulated with ethanol vehicle, $100 \mathrm{nM}$ TPA or 1,25 -VD for $3 \mathrm{~h} .30 \mu \mathrm{g}$ of nuclear extract was incubated with either wild-type- or mt-AP-1 probes as described in Materials and methods. After DNA pull-down assay was performed, proteins in the resulting DNA-protein complexes were separated by $10 \%$ SDS-PAGE and analyzed for the c-Jun by immunoblot analysis. The nuclear extracts (lanes 7-9) represent $50 \%$ of protein used in the pull-down assay. The level of DNA binding was extrapolated by densitometric analysis and values represent the fold changes relative to untreated control PC-3 cells. N.S., non-specific.

regulatory region is located between nucleotides -2350 and -1870 (30), yet no known vitamin D inhibitory sequences were found within that region. The changes of PA systems in response to $1,25-\mathrm{VD}$ seem to be cell-type specific. In keratinocytes and breast cancer cells, 1,25-VD down-regulates PAs and up-regulates PAI-1, whereas in sarcoma cells and phagocytes PA activities are enhanced and PAIs are suppressed (30,57-59). Hoosein et al. (61) reported that the presence of UPAR in PC-3 and DU 145 cells was correlated with high invasive ability, whereas LNCaP cells, which lack uPAR, have poor invasive ability. We also found that endogenous
mRNA expressions of uPA and uPAR are much higher in PC-3 and DU 145 compared to LNCaP cells (Figure 3C and Supplementary Figure 2), however, 1,25-VD treatment slightly induced total PA activities. These data indicate that PA activities might be important for cancer cell invasion, but that 1,25 -VD has no effect on the PA system in achieving its anti-invasive effects in human prostate cancer cell lines.

Increased expression and activity of CPs are seen in osteoclastomas, melanomas, gliomas, breast, colorectal, gastric, lung and prostate carcinomas (12-15), suggesting that these proteases might be involved in the development, invasion and 
metastasis of cancer cells. However, up-regulation of CP B and increased apoptosis after 1,25-VD treatment was found in the MCF-7 human breast cancer cell line (62). Similarly, 1,25-VD induced $C P D$ gene expression and differentiation in the HL60 human myeloid leukemia cell line (63). These findings suggested that $\mathrm{CP}$ might have other biological functions besides promoting cancer cell invasion. Nevertheless, the effects of 1,25-VD on CPs and CPIs in prostate cancer development and metastases have not been established. CP H and cystatin $\mathrm{M}$ have been shown to be down-regulated and upregulated by $1,25-\mathrm{VD}$ in squamous carcinoma cells, respectively (64). Cystatin A expression and promoter activity also can be up-regulated by $1,25-\mathrm{VD}$ in human keratinocytes (65). From our data, 1,25-VD effects on CP activity were not consistent among the three cell lines we used. CP activity was down-regulated in LNCaP and DU 145 cells, but up-regulated in PC-3 cells (Figure 4A), yet 1,25-VD enhanced CPI activities in all the cell lines (Figure 4B). However, the mRNA expression of potential targets, CP B, CP H, CP L, cystatin A and cystatin $\mathrm{M}$, showed no significant change upon 1,25-VD treatment. Therefore, the net $\mathrm{CP}$ protease activities, calculated by the C:I ratio, were decreased by $1,25-\mathrm{VD}$ treatment, which might contribute to the anti-invasion action of $1,25-\mathrm{VD}$, but potential targets and detailed mechanisms need to be further investigated.

Among the three major groups of proteases and their inhibitors we tested, TIMP- 1 is the most promising target for the anti-invasive effects of $1,25-\mathrm{VD}$ in human prostate cancer cells. Experiments have shown that recombinant TIMP-1 (rTIMP-1) inhibits the invasion of tumor cells through amniotic membranes (66). Administering rTIMP-1 to mice injected with metastatic B16 melanoma cells also inhibits the formation of lung metastases (66). TIMPs are able to inhibit the active forms of all of the MMPs. These data all suggest that the invasive and metastatic ability of cancer cells can be altered by changing the MMP:TIMP ratio. A concomitant increase in the secretion of TIMP-1 and, to a slightly lower extent, TIMP2 by $1,25-\mathrm{VD}$ was observed in MDA-MB-231 human breast cancer cells (30). As we have shown in Figure $2 \mathrm{C}$ and E, TIMP-1 activity and expression were increased by $1,25-\mathrm{VD}$ treatment. The $1.7 \mathrm{~kb}$ TIMP- 1 promoter contains at least 10 consensus binding sites for SP-1, 6 for AP-1, 6 for PEA3, 12 for AP-2 and 5 CCAAT boxes. (41). Point mutations confirmed that the AP- 1 site at $-92 /-86$ is essential for basal expression and for TPA to induce this gene. Several lines of evidence indicate that 1,25 -VD can increase the gene transcriptional activity via modulation of AP-1 abundance or DNA binding activity $(67,68)$. Here, we provide strong evidence showing that 1,25 -VD activates the TIMP-1 promoter through an AP-1 site, and the AP-1 site with a point-mutation in the TIMP-1 promoter diminishes the 1,25-VD response (Figures 5C and 6B). DNA pull-down assays demonstrated that $1,25-\mathrm{VD}$ induced the active AP-1 complexes, which then bound to the TIMP-1 promoter to induce TIMP-1 expression.

Metastases are responsible for most cancer mortalities, and any indication of metastatic cells would therefore justify aggressive therapy. Invasion of the basement membrane is a critical step in the metastatic cascade, therefore agents that inhibit invasiveness have obvious potential as anticancer drugs. Our study demonstrates that 1,25-VD significantly inhibits human prostate cancer cell invasion. This inhibition of invasion is associated with a decrease in MMP-9 protease activity and an increase in the production of protease inhibitors, such as TIMP-1 or CPIs. The ability of 1,25 -VD to inhibit cancer cell invasion supports clinical uses of 1,25 VD in the treatment of advanced stage prostate cancer, and may lead to more effective vitamin D-based therapeutics designed to control the metastatic potential of many tumors.

\section{Supplementary material}

Supplementary material can be found at: http://www.carcin. oxfordjournals.org/

\section{Acknowledgements}

We are grateful to Dr Lise Binderup from Leo Pharmaceutical Products for providing the 1,25-VD; Dr Yasuyuki Sasaguri from University of Occupational and Environmental Health, Japan, for MMP-9 promoter construct; Dr Andrew M.-L. Chan from Mount Sinai School of Medicine, NY for AP-1 and NF- $\mathrm{KB}$ reporter constructs; and Dr Ian M.Clark from University of East Anglia, UK, for TIMP-1 promoter constructs. We also thank Loretta Collins and Karen Wolf for manuscript preparation. This work was supported by the Department of Defense grant PC040630 and the New York Academy of Medicine Edwin Beer Research Fund.

Conflict of Interest Statement: None declared.

\section{References}

1. Meyer,T. and Hart,I.R. (1998) Mechanisms of tumour metastasis. Eur. J. Cancer, 34, 214-221.

2. Chambers,A.F. and Matrisian,L.M. (1997) Changing views of the role of matrix metalloproteinases in metastasis. J. Natl Cancer Inst., 89, 12601270 .

3. Stetler-Stevenson,W.G., Hewitt,R. and Corcoran,M. (1996) Matrix metalloproteinases and tumor invasion: from correlation and causality to the clinic. Semin. Cancer Biol., 7, 147-154.

4.Bernhard,E.J., Gruber,S.B. and Muschel,R.J. (1994) Direct evidence linking expression of matrix metalloproteinase 9 (92-kDa gelatinase/ collagenase) to the metastatic phenotype in transformed rat embryo cells. Proc. Natl Acad. Sci. USA, 91, 4293-4297.

5.Zucker,S., Lysik,R.M., Zarrabi,M.H. and Moll,U. (1993) M(r) 92,000 type IV collagenase is increased in plasma of patients with colon cancer and breast cancer. Cancer Res., 53, 140-146.

6. Mook,O.R., Frederiks,W.M. and Van Noorden,C.J. (2004) The role of gelatinases in colorectal cancer progression and metastasis. Biochim. Biophys. Acta, 1705, 69-89.

7. Dano,K., Andreasen,P.A., Grondahl-Hansen,J., Kristensen,P., Nielsen,L.S. and Skriver,L. (1985) Plasminogen activators, tissue degradation, and cancer. Adv. Cancer Res., 44, 139-266.

8. Laiho,M. and Keski-Oja,J. (1989) Growth factors in the regulation of pericellular proteolysis: a review. Cancer Res., 49, 2533-2553.

9.Holst-Hansen,C., Johannessen,B., Hoyer-Hansen,G., Romer,J., Ellis,V. and Brunner,N. (1996) Urokinase-type plasminogen activation in three human breast cancer cell lines correlates with their in vitro invasiveness. Clin. Exp. Metastasis, 14, 297-307.

10. Grondahl-Hansen,J., Christensen,I.J., Rosenquist,C., Brunner,N., Mouridsen,H.T., Dano,K. and Blichert-Toft,M. (1993) High levels of urokinase-type plasminogen activator and its inhibitor PAI-1 in cytosolic extracts of breast carcinomas are associated with poor prognosis. Cancer Res., 53, 2513-2521.

11. Castiglioni,T., Merino,M.J., Elsner,B., Lah,T.T., Sloane,B.F. and EmmertBuck,M.R. (1994) Immunohistochemical analysis of cathepsins D, B, and L in human breast cancer. Hum. Pathol., 25, 857-862.

12.Poole,A.R., Tiltman,K.J., Recklies,A.D. and Stoker,T.A. (1978) Differences in secretion of the proteinase cathepsin B at the edges of human breast carcinomas and fibroadenomas. Nature, 273, 545-547.

13.Sinha,A.A., Wilson,M.J., Gleason,D.F., Reddy,P.K., Sameni,M. and Sloane,B.F. (1995) Immunohistochemical localization of cathepsin B in neoplastic human prostate. Prostate, 26, 171-178.

14. Sloane,B.F., Dunn,J.R. and Honn,K.V. (1981) Lysosomal cathepsin B: correlation with metastatic potential. Science, 212, 1151-1153.

15.Page,A.E., Warburton,M.J., Chambers,T.J., Pringle,J.A. and Hayman,A.R. (1992) Human osteoclastomas contain multiple forms of cathepsin B. Biochim. Biophys. Acta, 1116, 57-66. 
16. Guinec,N., Dalet-Fumeron,V. and Pagano,M. (1993) In vitro study of basement membrane degradation by the cysteine proteinases, cathepsins B, B-like and L. Digestion of collagen IV, laminin, fibronectin, and release of gelatinase activities from basement membrane fibronectin. Biol. Chem. Hoppe Seyler., 374, 1135-1146.

17.Lah,T.T., Buck,M.R., Honn,K.V., Crissman,J.D., Rao,N.C., Liotta,L.A. and Sloane,B.F. (1989) Degradation of laminin by human tumor cathepsin B Clin. Exp. Metastasis, 7, 461-468.

18. Mason,R.W., Johnson,D.A., Barrett,A.J. and Chapman,H.A. (1986) Elastinolytic activity of human cathepsin L. Biochem. J., 233, 925-927.

19. Kastelic,L., Turk,B., Kopitar-Jerala,N., Stolfa,A., Rainer,S., Turk,V. and Lah,T.T. (1994) Stefin B, the major low molecular weight inhibitor in ovarian carcinoma. Cancer Lett., 82, 81-88.

20.Lah,T.T., Clifford,J.L., Helmer,K.M., Day,N.A., Moin,K., Honn,K.V., Crissman,J.D. and Sloane,B.F. (1989) Inhibitory properties of low molecular mass cysteine proteinase inhibitors from human sarcoma. Biochim. Biophys. Acta, 993, 63-73.

21. Kolar,Z., Jarvinen,M. and Negrini,R. (1989) Demonstration of proteinase inhibitors cystatin A, B and C in breast cancer and in cell lines MCF-7 and ZR-75-1. Neoplasma, 36, 185-189.

22. Hanchette,C.L. and Schwartz,G.G. (1992) Geographic patterns of prostate cancer mortality. Evidence for a protective effect of ultraviolet radiation. Cancer, 70, 2861-2869.

23. Schwartz,G.G. and Hulka,B.S. (1990) Is vitamin D deficiency a risk factor for prostate cancer? (Hypothesis). Anticancer Res., 10, 1307-1311.

24. Young,M.R., Halpin,J., Hussain,R., Lozano,Y., Djordjevic,A., Devata,S., Matthews,J.P. and Wright,M.A. (1993) Inhibition of tumor production of granulocyte-macrophage colony-stimulating factor by 1 alpha, 25dihydroxyvitamin D3 reduces tumor motility and metastasis. Invasion Metastasis, 13, 169-177.

25. Schwartz,G.G., Wang,M.H., Zang,M., Singh,R.K. and Siegal,G.P. (1997) 1 alpha,25-Dihydroxyvitamin D (calcitriol) inhibits the invasiveness of human prostate cancer cells. Cancer Epidemiol Biomarkers Prev., 6, 727-7132.

26. Hansen,C.M., Frandsen,T.L., Brunner,N. and Binderup,L. (1994) 1 alpha,25-Dihydroxyvitamin D3 inhibits the invasive potential of human breast cancer cells in vitro. Clin. Exp. Metastasis, 12, 195-202.

27. Konety,B.R., Lavelle,J.P., Pirtskalaishvili,G. et al. (2001) Effects of vitamin D (calcitriol) on transitional cell carcinoma of the bladder in vitro and in vivo. J. Urol., 165, 253-258.

28. Beer,T.M., Eilers,K.M., Garzotto,M., Egorin,M.J., Lowe,B.A. and Henner,W.D. (2003) Weekly high-dose calcitriol and docetaxel in metastatic androgen-independent prostate cancer. J. Clin. Oncol., 21, $123-128$.

29. Beer,T.M., Eilers,K.M., Garzotto,M., Hsieh,Y.C. and Mori,M. (2004) Quality of life and pain relief during treatment with calcitriol and docetaxel in symptomatic metastatic androgen-independent prostate carcinoma. Cancer, 100, 758-763.

30. Koli,K. and Keski-Oja,J. (2000) 1alpha,25-dihydroxyvitamin D3 and its analogues down-regulate cell invasion-associated proteases in cultured malignant cells. Cell Growth Differ., 11, 221-229.

31. Friberger,P., Knos,M., Gustavsson,S., Aurell,L. and Claeson,G. (1978) Methods for determination of plasmin, antiplasmin and plasminogen by means of substrate S-2251. Haemostasis, 7, 138-145.

32. Mayer,P., Schmid,H., Schaber,B. and Fierlbeck,G. (1997) Tumorassociated cysteine proteinase activities in human melanoma cells and fibroblasts of different origin. Eur. J Cell. Biol., 73, 344-351.

33. Kirschke,H., Wood,L., Roisen,F.J. and Bird,J.W. (1983) Activity of lysosomal cysteine proteinase during differentiation of rat skeletal muscle. Biochem. J., 214, 871-877.

34. Kato,Y., Yamashita,T. and Ishikawa,M. (2002) Relationship between expression of matrix metalloproteinase- 2 and matrix metalloproteinase- 9 and invasion ability of cervical cancer cells. Oncol. Rep., 9, 565-569.

35. Ottino,P., Taheri,F. and Bazan,H.E. (2002) Platelet-activating factor induces the gene expression of TIMP-1, -2, and PAI-1: imbalance between the gene expression of MMP-9 and TIMP-1 and -2. Exp. Eye Res., 74, 393-402.

36. Castello,R., Estelles,A., Vazquez,C., Falco,C., Espana,F., Almenar,S.M., Fuster,C. and Aznar,J. (2002) Quantitative real-time reverse transcriptionPCR assay for urokinase plasminogen activator, plasminogen activator inhibitor type 1 , and tissue metalloproteinase inhibitor type 1 gene expressions in primary breast cancer. Clin. Chem., 48, 1288-1295.

37. Grigolo,B., Roseti,L., Fiorini,M., Piacentini,A., De Franceschi,L. and Facchini,A. (2003) Cathepsin B as a soluble marker to monitor the phenotypic stability of engineered cartilage. Biomaterials, 24, 1751-1757.
38. Guttentag,S., Robinson,L., Zhang,P., Brasch,F., Buhling,F. and Beers,M (2003) Cysteine protease activity is required for surfactant protein B processing and lamellar body genesis. Am. J. Respir. Cell Mol. Biol., 28 69-79.

39. Alevizos,I., Mahadevappa,M., Zhang,X. et al. (2001) Oral cancer in vivo gene expression profiling assisted by laser capture microdissection and microarray analysis. Oncogene, 20, 6196-6204.

40.Livak,K.J. and Schmittgen,T.D. (2001) Analysis of relative gene expression data using real-time quantitative PCR and the 2(-Delta Delta C(T)) Method. Methods, 25, 402-408

41.Clark,I.M., Rowan,A.D., Edwards,D.R., Bech-Hansen,T., Mann,D.A., Bahr,M.J. and Cawston,T.E. (1997) Transcriptional activity of the human tissue inhibitor of metalloproteinases 1 (TIMP-1) gene in fibroblasts involves elements in the promoter, exon 1 and intron 1. Biochem. J., 324, 611-617.

42. Andrews,N.C. and Faller,D.V. (1991) A rapid micropreparation technique for extraction of DNA-binding proteins from limiting numbers of mammalian cells. Nucleic Acids Res., 19, 2499.

43. Bao,B.Y., Hu,Y.C., Ting,H.J. and Lee,Y.F. (2004) Androgen signaling is required for the vitamin D-mediated growth inhibition in human prostate cancer cells. Oncogene, 23, 3350-3360.

44.Ly,L.H., Zhao,X.Y., Holloway,L. and Feldman,D. (1999) Liarozole acts synergistically with 1alpha,25-dihydroxyvitamin D3 to inhibit growth of DU 145 human prostate cancer cells by blocking 24-hydroxylase activity. Endocrinology, 140, 2071-2076.

45. Skowronski,R.J., Peehl,D.M. and Feldman,D. (1993) Vitamin D and prostate cancer: 1,25 dihydroxyvitamin D3 receptors and actions in human prostate cancer cell lines. Endocrinology, 132, 1952-1960.

46. Barrett,A.J. and Kirschke,H. (1981) Cathepsin B, Cathepsin H, and cathepsin L. Methods Enzymol., 80 Pt C, 535-561.

47. Beer,T.M. and Myrthue,A. (2004) Calcitriol in cancer treatment: from the lab to the clinic. Mol. Cancer Ther., 3, 373-381.

48. Mantell,D.J., Owens,P.E., Bundred,N.J., Mawer,E.B. and Canfield,A.E. (2000) 1 alpha,25-dihydroxyvitamin $\mathrm{D}(3)$ inhibits angiogenesis in vitro and in vivo. Circ Res., 87, 214-220.

49. Lacraz,S., Dayer,J.M., Nicod,L. and Welgus,H.G. (1994) 1,25dihydroxyvitamin D3 dissociates production of interstitial collagenase and $92-\mathrm{kDa}$ gelatinase in human mononuclear phagocytes. J. Biol. Chem., 269, 6485-6490.

50. Sato,H. and Seiki,M. (1993) Regulatory mechanism of 92 kDa type IV collagenase gene expression which is associated with invasiveness of tumor cells. Oncogene, 8, 395-405.

51. Gum,R., Wang,H., Lengyel,E., Juarez,J. and Boyd,D. (1997) Regulation of $92 \mathrm{kDa}$ type IV collagenase expression by the jun aminoterminal kinaseand the extracellular signal-regulated kinase-dependent signaling cascades. Oncogene, 14, 1481-1493.

52.Liu,P., Kimmoun,E., Legrand,A., Sauvanet,A., Degott,C., Lardeux,B. and Bernuau,D. (2002) Activation of NF-kappa B, AP-1 and STAT transcription factors is a frequent and early event in human hepatocellular carcinomas. J. Hepatol., 37, 63-71.

53.Zeigler,M.E., Chi,Y., Schmidt,T. and Varani,J. (1999) Role of ERK and JNK pathways in regulating cell motility and matrix metalloproteinase 9 production in growth factor-stimulated human epidermal keratinocytes. $J$. Cell Physiol., 180, 271-284.

54. Hozumi,A., Nishimura,Y., Nishiuma,T., Kotani,Y. and Yokoyama,M. (2001) Induction of MMP-9 in normal human bronchial epithelial cells by TNF-alpha via NF-kappa B-mediated pathway. Am J Physiol Lung Cell Mol Physiol., 281, L1444-L1452.

55. Yu,X.P., Bellido,T. and Manolagas,S.C. (1995) Down-regulation of NFkappa B protein levels in activated human lymphocytes by 1,25dihydroxyvitamin D3. Proc. Natl Acad. Sci. USA, 92, 10990-10994.

56. Harant,H., Wolff,B. and Lindley,I.J. (1998) 1Alpha,25-dihydroxyvitamin D3 decreases DNA binding of nuclear factor-kappaB in human fibroblasts. FEBS Lett, 436, 329-334.

57. Gyetko,M.R., Webb,A.C. and Sitrin,R.G. (1988) Modulation of urokinasetype plasminogen activator and plasminogen activator inhibitor-2 expression by U-937 mononuclear phagocytes. Effects of 1 alpha, 25dihydroxyvitamin D3 and phorbol ester. J. Immunol., 141, 2693-2698.

58. Fukumoto,S., Allan,E.H. and Martin,T.J. (1994) Regulation of plasminogen activator inhibitor-1 (PAI-1) expression by 1,25-dihydroxyvitamin D3 in normal and malignant rat osteoblasts. Biochim. Biophys. Acta, 1201, 223-228.

59. Koli,K. and Keski-Oja,J. (1993) Vitamin D3 and calcipotriol decrease extracellular plasminogen activator activity in cultured keratinocytes. J. Invest. Dermatol., 101, 706-712. 


\section{B.-Y.Bao, S.-D.Yeh and Y.-F.Lee}

60. Verde,P., Boast,S., Franze,A., Robbiati,F. and Blasi,F. (1988) An upstream enhancer and a negative element in the $5^{\prime}$ flanking region of the human urokinase plasminogen activator gene. Nucleic Acids Res., 16, 10699-10716.

61.Hoosein,N.M., Boyd,D.D., Hollas,W.J., Mazar,A., Henkin,J. and Chung,L.W. (1991) Involvement of urokinase and its receptor in the invasiveness of human prostatic carcinoma cell lines. Cancer Commun., 3, 255-264.

62.Simboli-Campbell,M., Narvaez,C.J., van Weelden,K., Tenniswood,M. and Welsh,J. (1997) Comparative effects of 1,25(OH)2D3 and EB1089 on cell cycle kinetics and apoptosis in MCF-7 breast cancer cells. Breast Cancer Res. Treat., 42, 31-41.

63. Atkins,K.B. and Troen,B.R. (1995) Regulation of cathepsin D gene expression in HL-60 cells by retinoic acid and calcitriol. Cell Growth Differ., 6, 871-877.

64. Lin,R., Nagai,Y., Sladek,R., Bastien,Y., Ho,J., Petrecca,K., Sotiropoulou,G., Diamandis,E.P., Hudson,T.J. and White,J.H. (2002) Expression profiling in squamous carcinoma cells reveals pleiotropic effects of vitamin D3 analog EB1089 signaling on cell proliferation, differentiation, and immune system regulation. Mol. Endocrinol., 16, 1243-1256.
65. Takahashi,H., Ibe,M., Honma,M., Ishida-Yamamoto,A., Hashimoto,Y. and Iizuka,H. (2003) 1,25-dihydroxyvitamin D(3) increases human cystatin A expression by inhibiting the Raf-1/MEK1/ERK signaling pathway of keratinocytes. Arch. Dermatol. Res., 295, 80-87.

66. Alvarez,O.A., Carmichael,D.F. and DeClerck,Y.A. (1990) Inhibition of collagenolytic activity and metastasis of tumor cells by a recombinant human tissue inhibitor of metalloproteinases. J. Natl. Cancer Inst., 82 , $589-595$.

67. Chen,A., Davis,B.H., Bissonnette,M., Scaglione-Sewell,B. and Brasitus,T.A. (1999) 1,25-Dihydroxyvitamin D(3) stimulates activator protein-1-dependent Caco-2 cell differentiation. J. Biol. Chem., 274, 35505-35513.

68. Yeung,F., Law,W.K., Yeh,C.H., Westendorf,J.J., Zhang,Y., Wang,R., Kao,C. and Chung,L.W. (2002) Regulation of human osteocalcin promoter in hormone-independent human prostate cancer cells. J. Biol. Chem., 277, 2468-2476.

Received March 1, 2005; revised June 19, 2005; accepted June 21, 2005 